\title{
Thinking Maps in Writing Project in English for Taiwanese Elementary School Students
}

\author{
Yu Shu Fan \\ Institute of Taiwan Languages and Language Teaching, National Hsinchu University of Education, Taiwan
}

Copyright $(\mathcal{C} 2016$ by authors, all rights reserved. Authors agree that this article remains permanently open access under the terms of the Creative Commons Attribution License 4.0 International License

\begin{abstract}
Thinking Maps is a language of eight visual patterns, each based on a fundamental thought process, designed by Dr. David N. Hyerle[1]. The visual patterns are based on cognitive skills and applied in all content areas. Not only are they used in different combinations for depth and complexity, but are also used by all members in the school community. Mt. Airy Elementary School, Maryland in the USA has achieved outstanding results after using Thinking Maps for years. Students in Taiwan are afraid of writing English essays, in which it becomes an island wide problem in all the schools. Using Thinking Maps while writing English essays helps the students in the elementary schools in Taiwan to start their English essay writing and build their structures in thinking and mapping their thoughts. Centre of College Entrance Examination in Taiwan ${ }^{1}$ declared in 2009 that more than 15 percentage of students had gotten a zero on their English writing. Only fewer researches are relevant to English writing during the past twenty years. The purpose of this teaching project tried to use Thinking Maps to build up the skills of English writing. Moreover, the researcher designed games in teaching. No matter the beginners or skill students enjoy English writing instead of fear. This writing project finds out that Thinking Maps help most of the students in developing good structure, providing more and more ideas for them to use in their own essay writing no matter if they have experience in writing or not. As a result, the students are confident in English writing, therefore, Thinking Maps is a new teaching method to be considered for all the teachers in Taiwan.
\end{abstract}

Keywords Thinking Maps, English Writing, Writing Project

\section{Introduction}

Thinking Maps are a language. Hyerle[1] has used the words model, approach, and tools to name and define the maps, but these are inadequate placeholders for what is really a new language for thinking and communicating. This language is grounded in and defined by eight every day,

\footnotetext{
${ }^{1}$ source from

http://newsletter.teldap.tw/news/ProgramTourismContent.php?nid=3251\&1 id $=325$
}

interdependent cognitive processes we use as human beings to make sense of our world and through which we survive. Thinking Maps are a pattern language in a nutshell and they are no different from other languages. They are a way for learners to become conscious of and transfer these mental operations into any learning environment, from early childhood to the adult workplace. Teachers use the maps to convey, facilitate, and mediate thinking and learning as every student becomes more fluent with the maps as a language. Flower[15] mentioned that writing is a constructive process, and writers make deliberate choices as they construct meaning. They apply strategies purposefully as they draw, revise, and edit their compositions. Researchers have found that Thinking Maps compositions are dramatically better than those of other students, and they attract struggling students. Chun [1] declared in 'The Singapore Experience' that Singapore is a multilingual country and that the Singapore government hosted International Thinking Conference in 1997. A year later, the teachers who had used Thinking Maps in their lessons in Singapore concluded that their pupils were better at organizing their writing, timing and organizational skills. Piercy and Hyerle [1] declared that Mt. Airy elementary School, Maryland, in the quantitative results on the school's state assessment has realized a $15 \%$ increase on the state-mandated assessment after one year. Later, Mt. Airy Elementary rose from being a school in the middle of testing to becoming the highest-performing school of the 21 elementary schools in Carroll County. Taiwanese students have a similar background as Singapore students do, therefore the researcher uses Thinking Maps in writing English curriculum in the elementary school. Thinking Maps are the paper for the mental mapping that goes on in our brain and through our minds. The early researchers generally divided the writing process into three stages. Britton [14] labeled them conception, incubation and production: In the conception stage, writers choose topics; in the incubation stage, they develop the topic by gathering information; and in the production stage, they write, revise, and edit their rough drafts. During the writing process, the writers think and do as they write stage by stage but Thinking Maps make English writing easier for Taiwanese students in the elementary schools. Students would rather draw their ideas on the paper than edit drafts. 
The first major task, the researcher undertook using the maps as a tool to facilitate student's thinking and decision making was the development of their writing program. Circle Maps are one of the Thinking Maps for defining things in context, to begin the process of responding to the question. Circle Maps give students a chance to formulate their ideas and also give the researcher an opportunity to consider the range of thinking before entering into conversation. Bubble maps can take the place of prewriting for some essays. Having the Bubble Maps give the students a common place to direct their attention and a central focus, the question and thinking.

- Teaching goal: Improving students writing skills by using Thinking Maps.

- Maps: Bubble Maps ,Tree Maps and Flow maps

- Teaching time: 2 weeks for 5 times of teaching.

- Students: A class of students who have been learning English for more than 2 years.

- The students have the same ability in grammar and literacy, but they are not in the same age group. They have learned simple present tense, present continuous tense, past tense, past continuous tense and future tense. Although they have known the tenses which are mentioned, they are still not ready to write a good essay by themselves. Thinking Maps provide a good way to build writing structures and get ideas together. It will be a good chance to use Thinking Maps.

- Teaching Materials: The students have learned the idea of the $3 \mathrm{R}^{2}$ s and have learned how important it is to protect our earth.

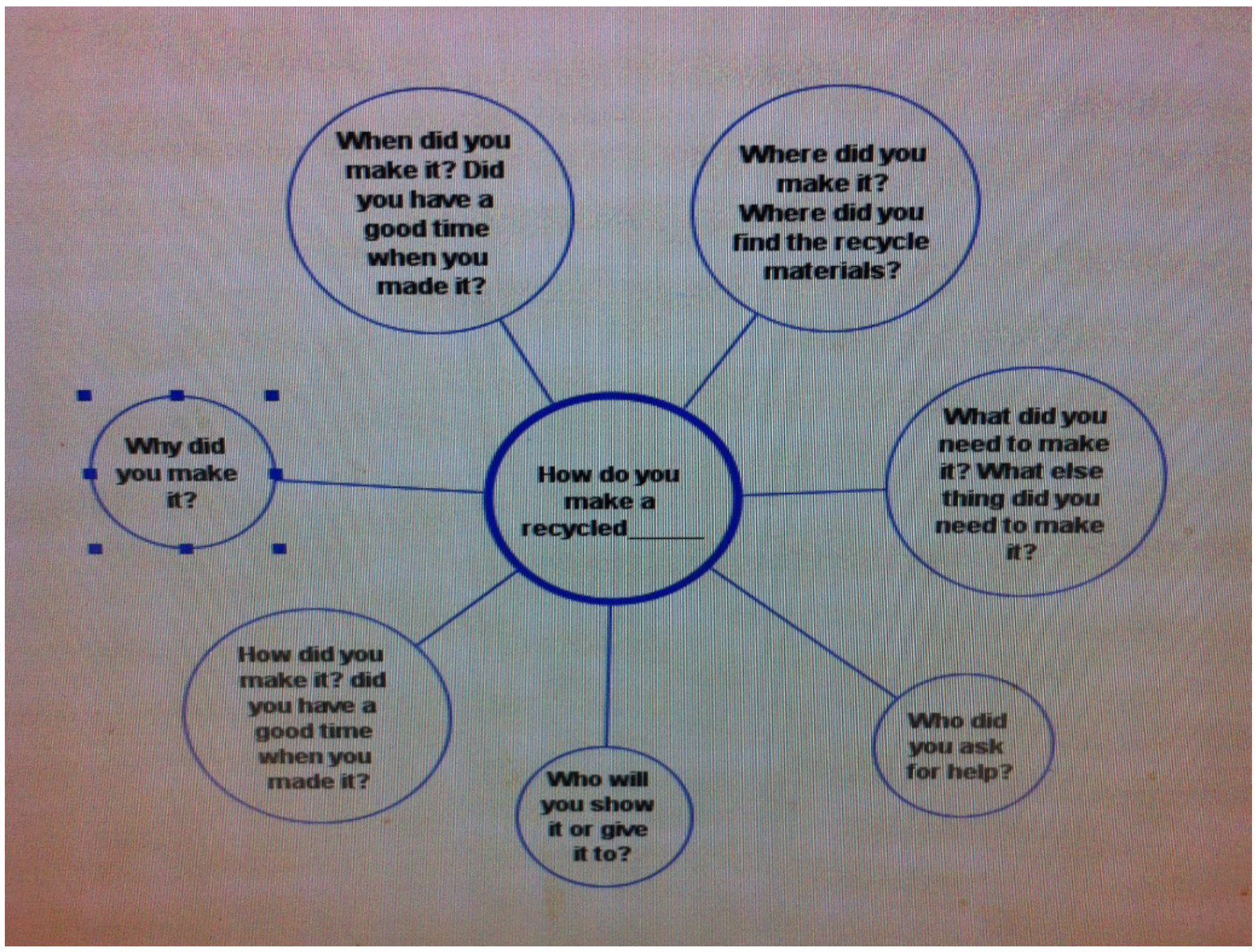

Figure 1. Map of the concepts (Circle Maps)

Warm up.

Activity: Let's think about it!

Props: coins

Instructions:-Brainstorm and work together in a group.

-Talking with partners, take turns to flip a coin. Heads=move one step. Tails= stand still. Answer the question for the circle you land on. The first one to stand on the finishing square is the winner.

\footnotetext{
${ }^{2}$ The 3R's represent recycle, reuse and reduce when people try to protect the environment.
} 


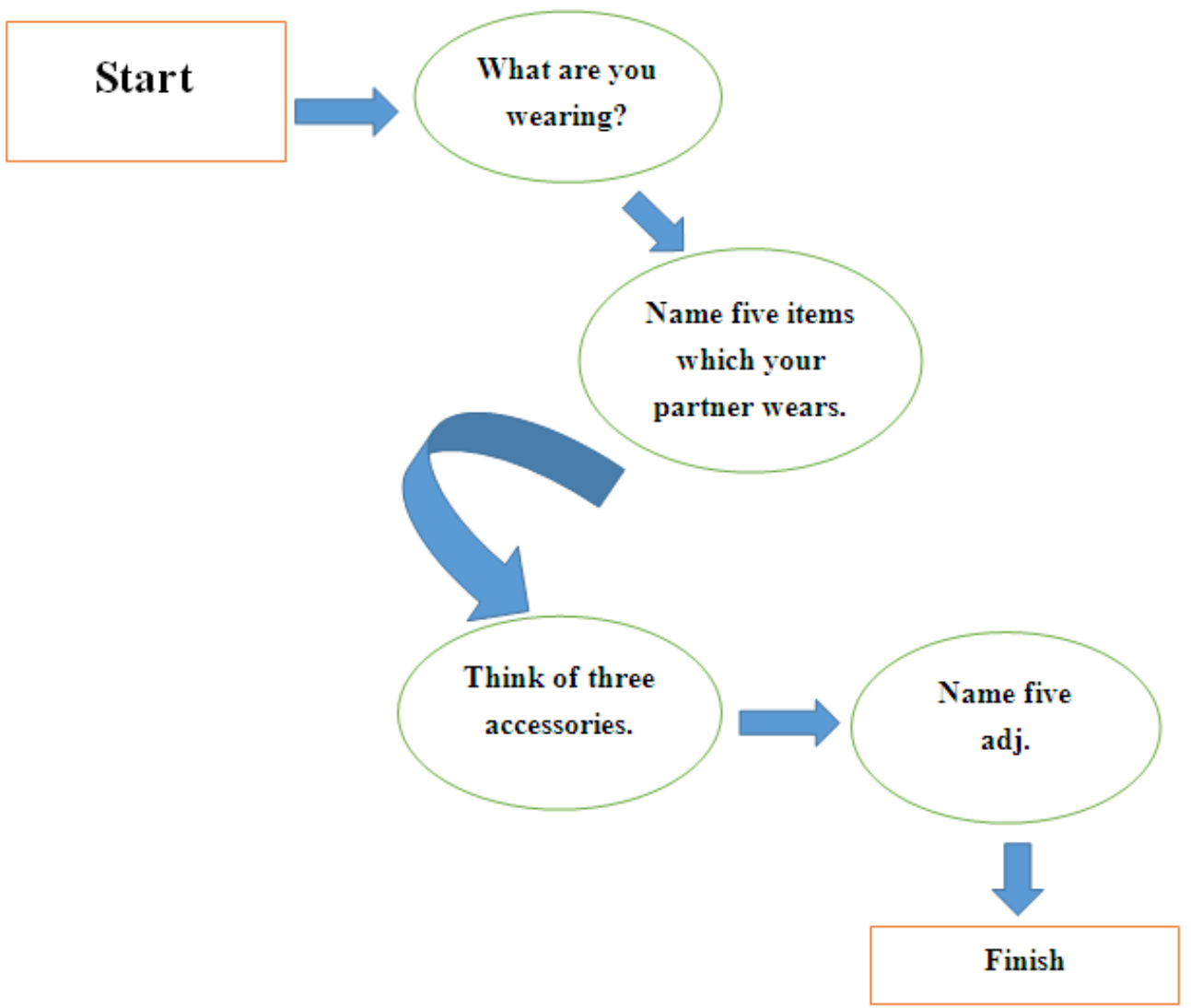

Writing Activity

Lesson one

Activity-Recycling Doll

- Vocabulary teaching:

- Warm up before you teach the new vocabulary including reviewing phonics which you may use in the writing.

- Activity: Let's Change it!

- Have two teams or more in your class. Have students stand at the front of the classroom and let them observe each other for one minute. After one minute they can point out the difference of each other's appearances. It doesn't matter if they use single words or sentences as long as they can sound it out.

Prepare props that you want on the table. The students may use the props which you have prepared. Allot 3 minutes to play this game.

- SETUP: Talk with the class how important the $3 \mathrm{R}^{3}$ 's are and then discuss how to recycle, how to protect our earth and the students can make their toys without paying. Brainstorm together for all kinds of various objects that you can recycle at home or from friends instead of throwing away.

- BUBBLE MAPS AND TREE MAPS DEMO: Have students call out objects to recycle as you write them on the board. When you have enough objects, you may draw a doll in a bubble and let the students come up one at one time to fill the part of a doll. When you are finished, ask the class what other kinds of things they can use to make a recycle doll. Encourage creativity.

- DO: Pass out paper and read through the different materials on the board together. Let the students know that they can use these or other things to draw their doll. Put students in pairs or small groups. You are a supervisor as you walk around the classroom to listen to them. Students should have chances to discuss what they want to make and what things they can use to make it before they start drawing their own doll.

- WRAP: Let groups come up front and tell the class about their doll: what it is made of and what it is special.

- Make Your Own Doll

\footnotetext{
${ }^{3} 3 R$ 's means recycle, reduce and reuse which presents an innovation how to preserve environment and generate knowledge.
} 


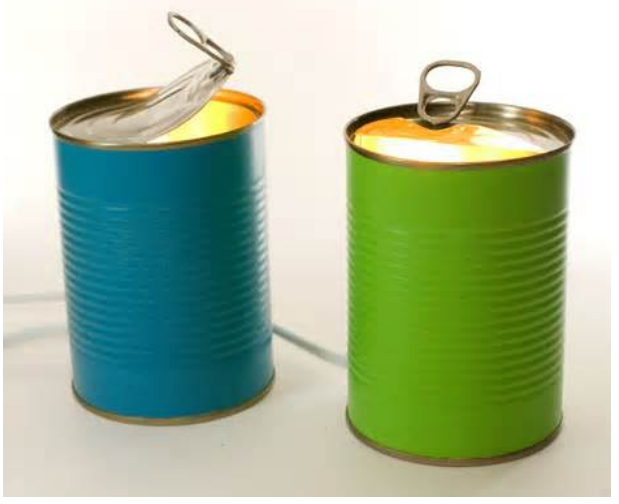

cans

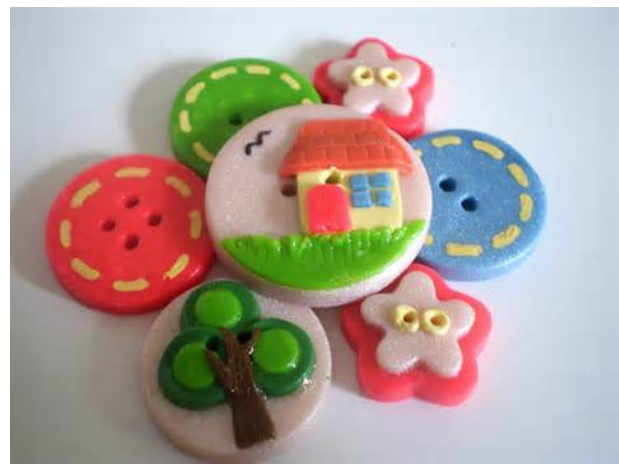

Buttons

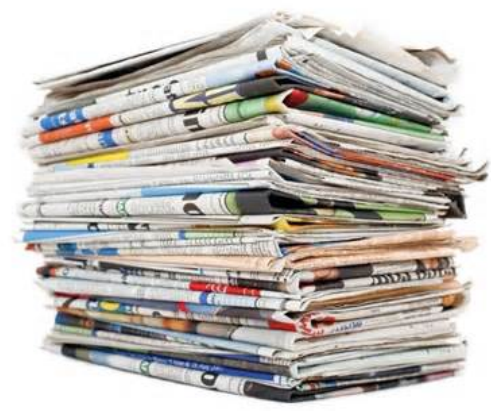

newspapers

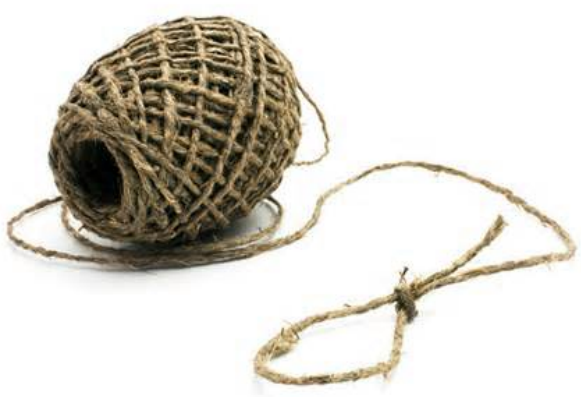

string

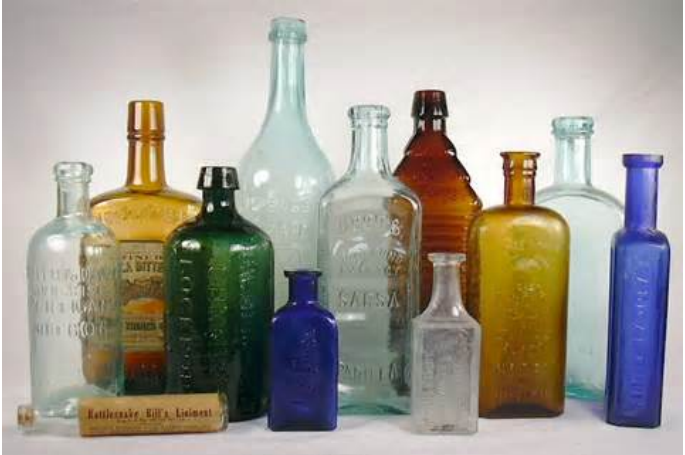

bottles

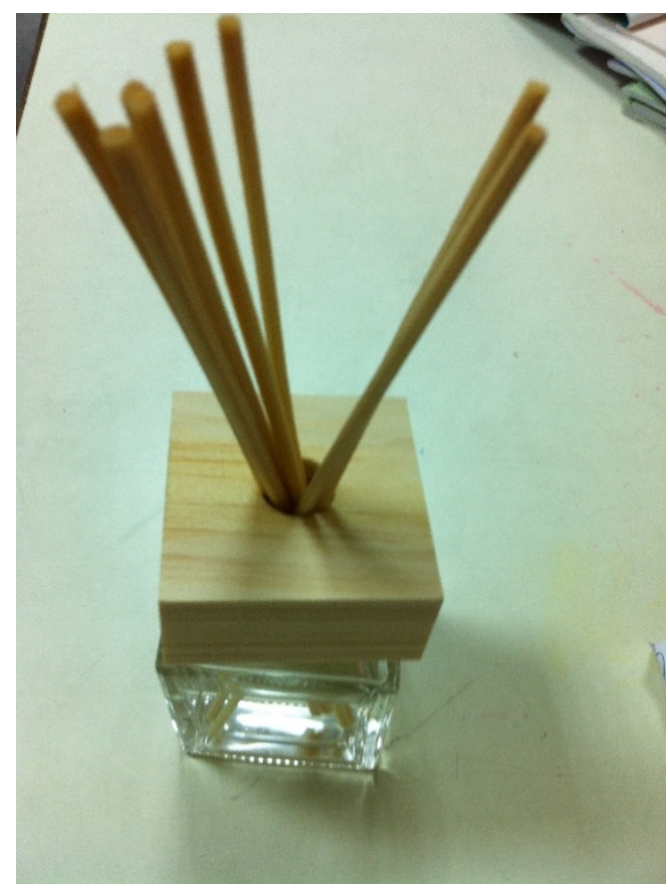

sticks 

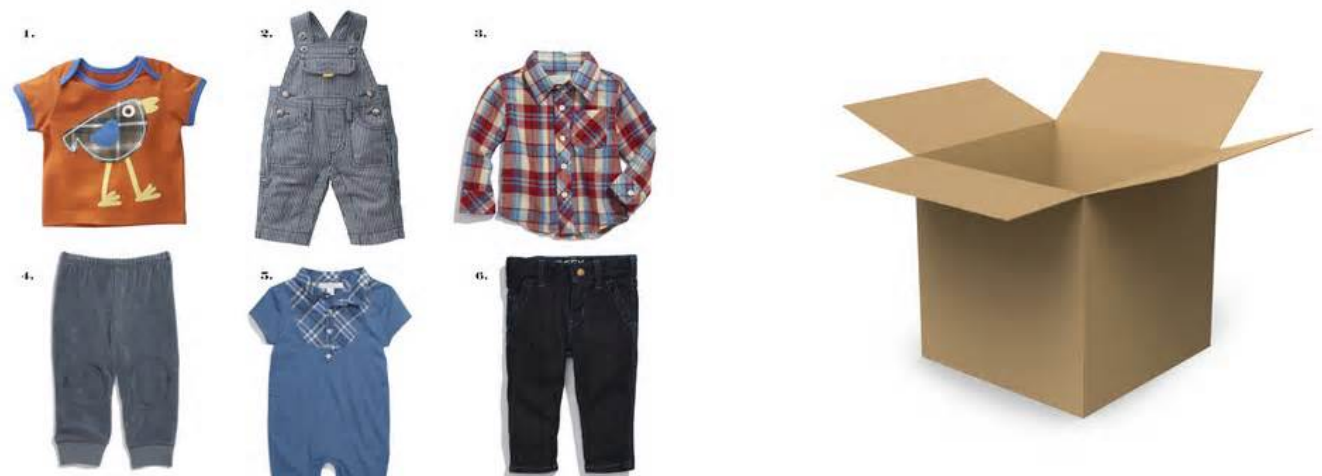

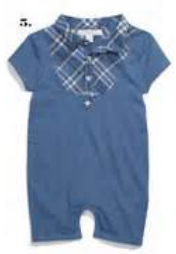

Clothes

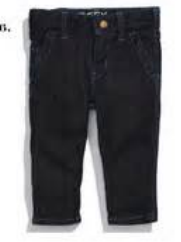

other things(The pictures are extracted from Yahoo website.)

Draw a robot from recycled trash.

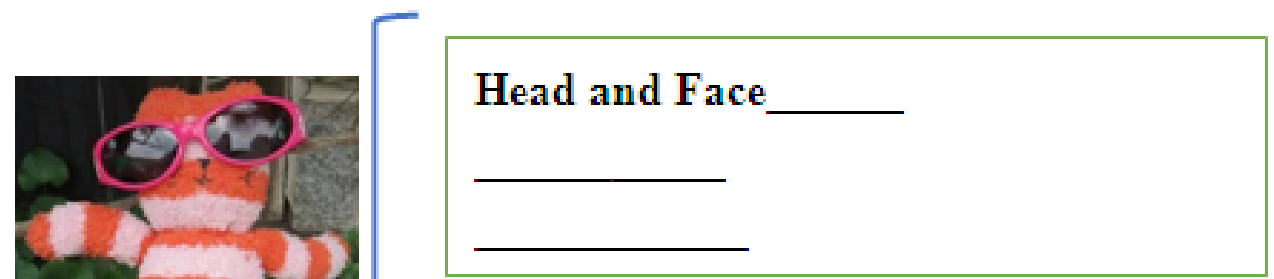

\section{Body}

\section{Arms}

\section{Legs}

Figure 2. Tree Maps

Lesson two

Writing Activity: Brainstorming

- BUBBLE MAPS AND TREE MAPS DEMO: Let students call out objects to recycle as you write them on the board. Introduce Bubble Maps and Tree Maps to the students then demo the maps on the white board. First draw a big bubble to write the topic which you would like to demo. Second, ask the students the $6 \mathrm{WH}$ questions draw more Bubble Maps on the white board to write down the ideas. (figure2-6) When you have enough ideas, start to write down key words or objects which the students 
need to make. You can let students come up one at a time and fill different Bubble Maps on the board. When you have more information, you may draw Tree Maps on the board to fill with more items.

- DO: Pass out paper and markers and read through the different Bubble Maps and Tree Maps together. Let the students know that they can use these or other things to draw their maps. Put students in pairs or small groups. When you are finished, guide students how to use the Bubble Maps and Tree Maps to show their ideas from their mind by themselves. Encourage creativity. Students should discuss what they want to make by themselves and what other things they can use to make it before they start drawing their own maps. While the students are drawing their own map, you may walk around the classroom and help them as soon as you see it.

- WRAP: Let groups or individual students come up front and tell the class about their Bubble Maps and Tree Maps. You may give them more ideas.

- Make Your Own Doll

- SET UP: Review the ideas students came up with for in the 'Brainstorming' activity and discuss things you can recycle \& what we can make with them. Write the questions from the hand out on the board.
Things we can make from recycled trash:

a recycle robot a pencil holder a paper lantern a paper toy gun a newspaper kite a newspaper mask a piggy bank a book holder

The following chart can be used to practice the students' oral ability and share the ideas from their classmates. When they have the images and ideas from their classmates, they would create more imagination in their essay writing.

\begin{tabular}{|c|c|c|}
\hline $\begin{array}{c}\text { What do you want to } \\
\text { make? } \\
\text { a doll }\end{array}$ & $\begin{array}{c}\text { What do you want } \\
\text { to make? }\end{array}$ & $\begin{array}{c}\text { What do you want to } \\
\text { make? }\end{array}$ \\
\hline $\begin{array}{c}\text { What recycled } \\
\text { materials will you } \\
\text { use? } \\
\text { buttons, string, a sock, } \\
\text { newspapers }\end{array}$ & $\begin{array}{c}\text { What recycled } \\
\text { materials will you } \\
\text { use? }\end{array}$ & $\begin{array}{c}\text { What recycled } \\
\text { materials will you } \\
\text { use? }\end{array}$ \\
\hline $\begin{array}{c}\text { What other things do } \\
\text { you need? } \\
\text { glue, markers, } \\
\text { scissors, tape, needle, } \\
\text { strings, } \\
\text { cotton }\end{array}$ & $\begin{array}{c}\text { What other things do } \\
\text { you need? }\end{array}$ & $\begin{array}{c}\text { What other things do } \\
\text { you need? }\end{array}$ \\
\hline
\end{tabular}

Figure 3. Activity Chart

After they ask the other classmates, they can draw Bubble Map as follows.

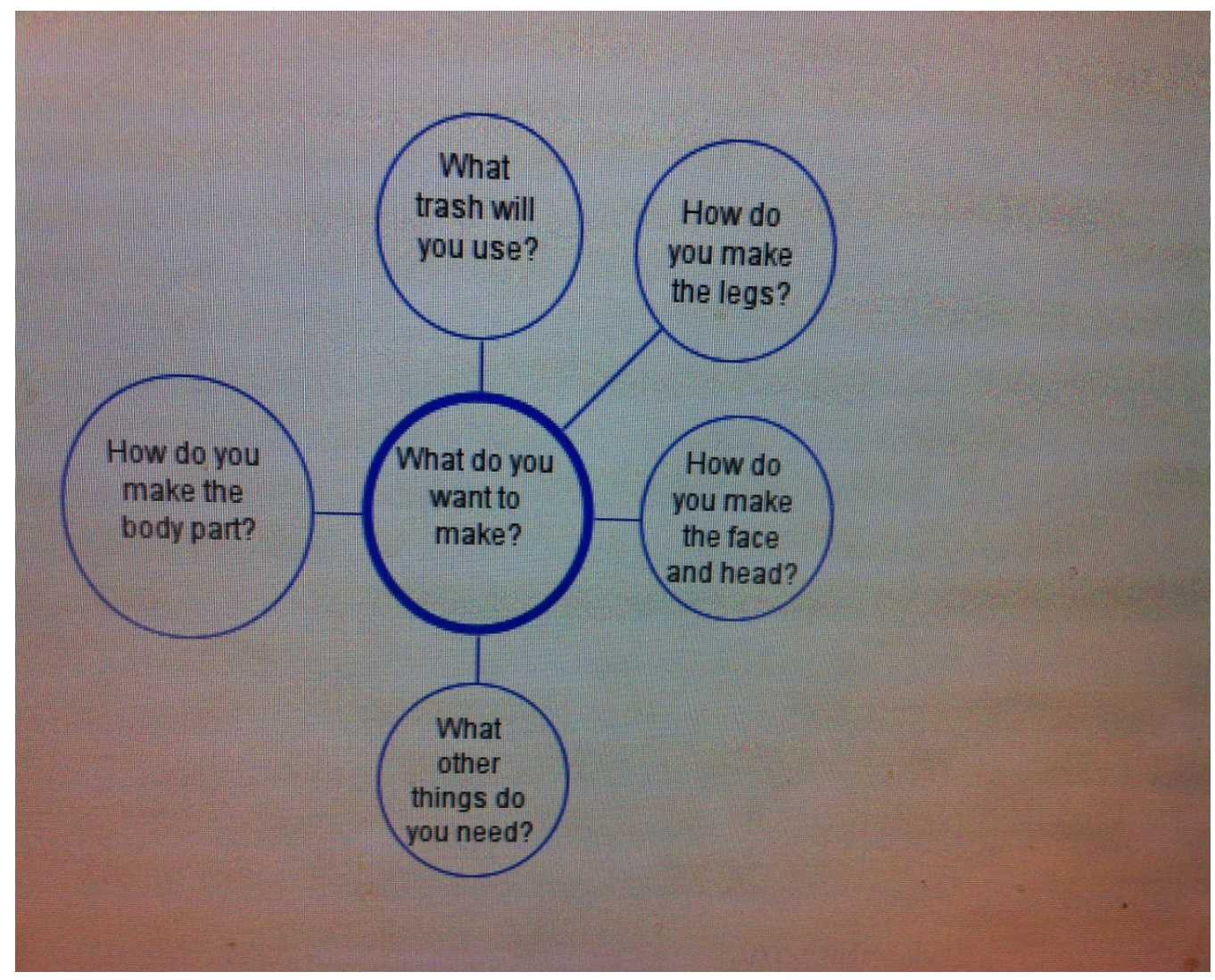

Figure 4. Bubble Maps 
Writing Activity Lesson 3

- SET UP: Review the ideas which students have in the previous "Brainstorming" activity. Make sure what students want to make, what recyclable items they have to use to make it, and what other things they need to make it. Write the 5 parts of an essay on the board as follows:

\section{Topic \\ Introduction \\ Body: First Paragraph \\ Body: Second Paragraph \\ Conclusion}

- DEMO: Talk about the different parts of the essay with the class: The 'topic' is the name of the essay. The "Introduction" is short paragraph which contains 3 or 4 sentences. The 'body' is very long; we write a lot of things to support the previous paragraph in the 'body' and give more information for it. The 'conclusion' paragraph maybe explain what function a conclusion stress. Go ahead and review the word 'paragraph': the introduction, body and conclusion are all paragraphs. You can also review the words 'indent' and 'indentation'.

- DO: Thinking Maps Essay Planning: Take out the hand outs and read the questions in the outline paragraph. Read the Flow Maps together. Show how each paragraph has an 'indentation' of 5 spaces. After the class has read it. Go back the questions ${ }^{4}$ and ask the students to answer the questions orally using their own Thinking Maps paper. For the 'Second Paragraph', have the students underline conjunctions in the essay. Teach the students how to write the sentences longer in using conjunctions.

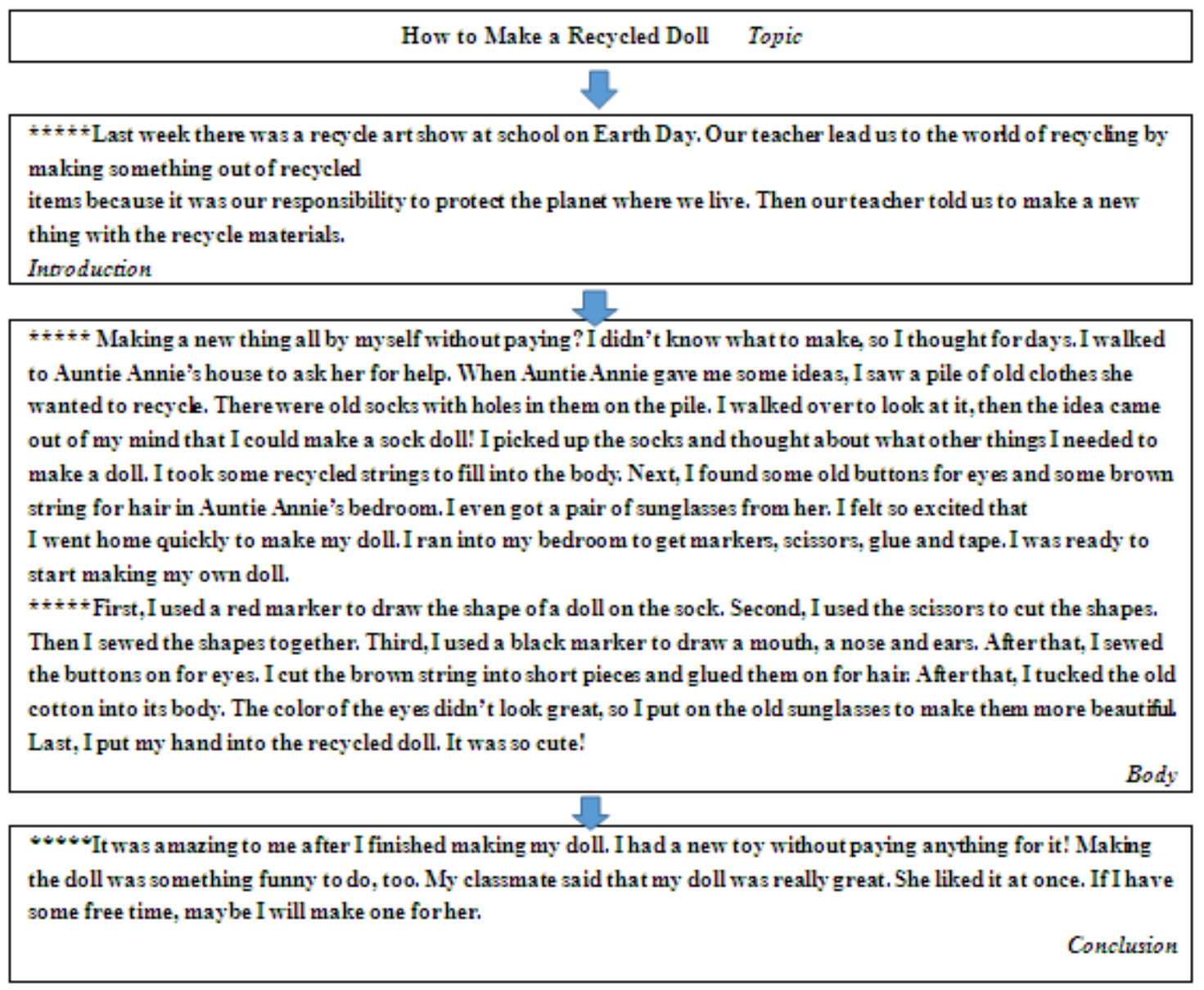

Figure 5. Thinking Maps Essay Planning

\footnotetext{
${ }^{4}$ To ask Wh-Questions according to the student's Thinking Maps.
} 
- On Your Own: Let the students decide what they are going to make and guide them as they fill in their Thinking Maps. They can use one of the ideas from the Brainstorming activity, or they can think of something new to write about. If they are slow at deciding, you can encourage them to write ideas down.

- Use Thinking Maps to condense the demo essay.

- On Your Own: Lesson four

Pretend that you finished making your recycled art. Please use the past tense and your Thinking Map to write your essay.

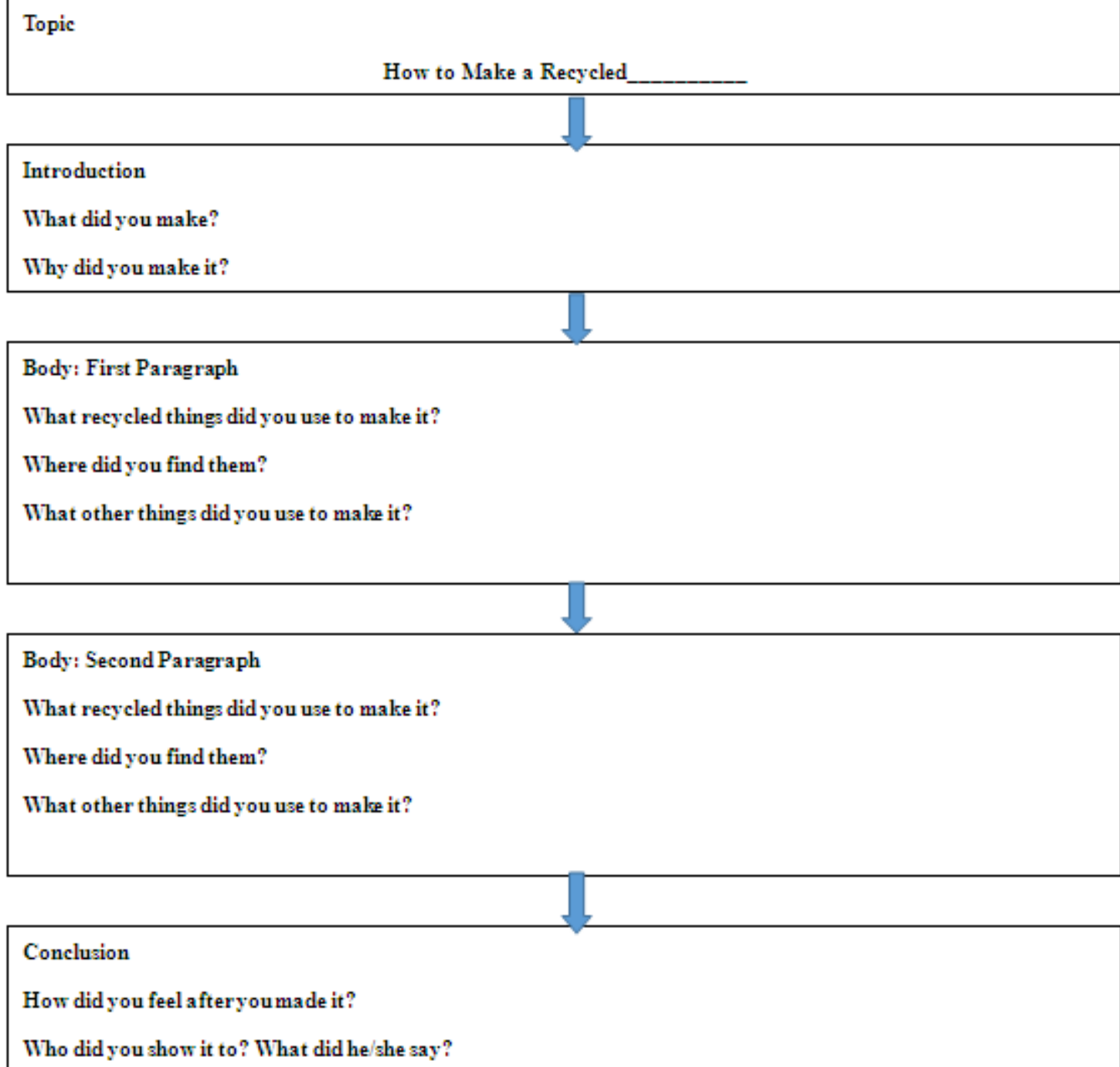

Figure 6. Flow Maps

- Lesson four-Use your own map to write your essay.

You may use Flow Map to write the main questions on each paragraphs. 


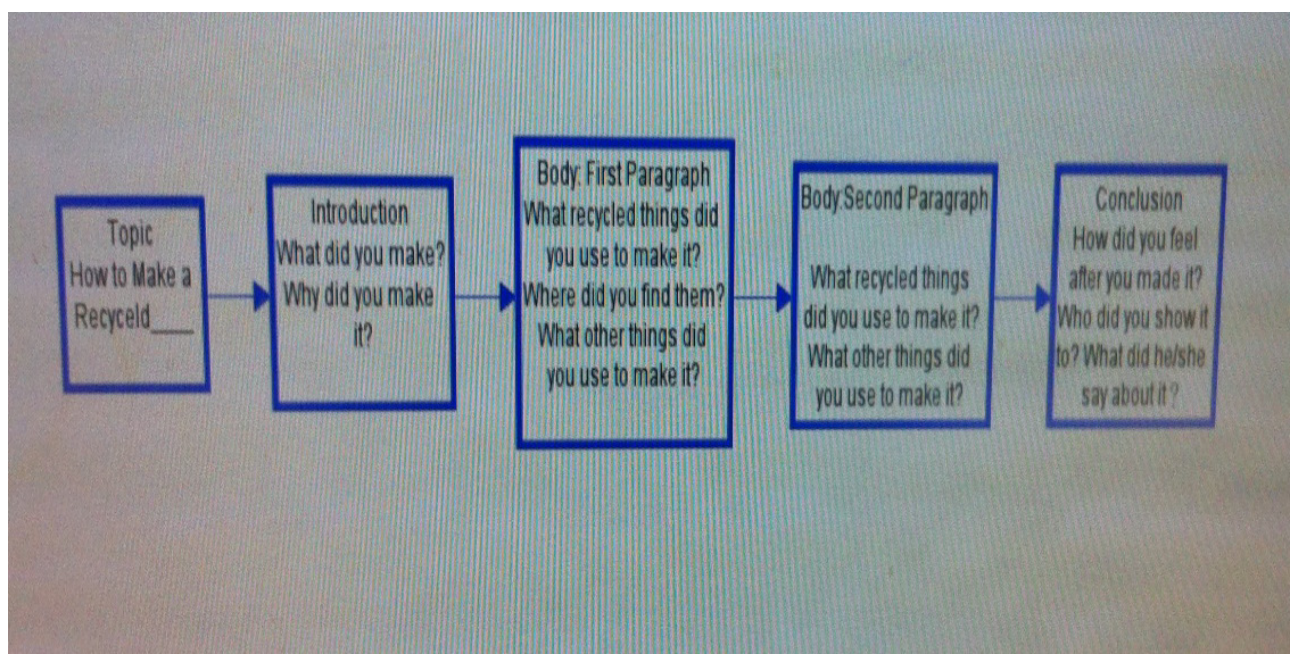

Figure 7. Flow Map

- Conjunctions- Encourage your students to use conjunctions to write longer sentences.

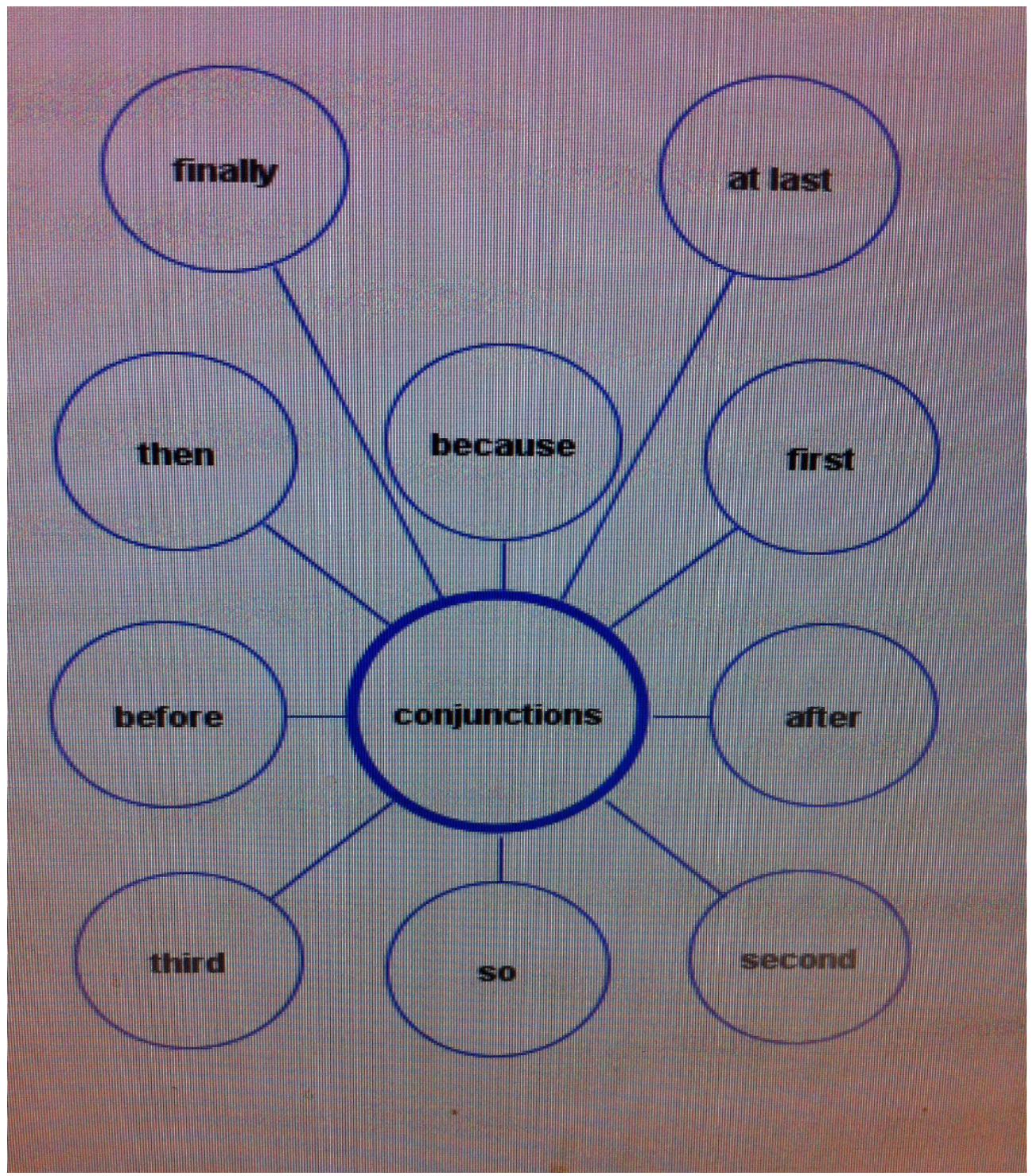

Figure 8. ' Conjunctions’ Bubble Maps 
- Lesson five- Proofread the finished essay and rewrite it again. If there are any mistakes, then have your students revise their essay. Encourage each student to come up to the front and read their own essay to everyone.

- Activity: Read out loud. Have the students in two teams, first ask them to name their team, then you may start your game. Set time for five minutes, then set the students in order. When the game starts, the first student from each team needs to come to the front and read their essay to everybody and it changes to the second one from the team. When the time is up, the students who are at the front reading have to do something funny, for example, they may tell a joke or sing a song.

- Goal of teaching:

1. The students can use the words and patterns they have learned.

2. The students can understand the demo reading.

3. Improving reading comprehension ability and having fun in reading and writing.

4. The students would like to use English to express themselves.

5. The students can write the essay by using Thinking Maps easily.

- Grading the essay

1. On-line grading of the essay -Criterion is
Educational Testing Service which was created by ETS Technologies, Inc.

2. Grading by the teachers-We can follow the grading system seen in figure 1 . On figure 1 was created by a group of professors from Taiwan to be used for the College Entrance Examination In Specified Subjects. Therefore, the total scores of essay writing will be 20 points, as we have the original scores then we should may times five to get the final scores.

- Conclusion of the First English Writing Project

After using Thinking Maps, the researcher interviewed and questioned the students about the problems they have faced. There are 17 students in this class and all of them thought English writing was a difficult job to do. After using Thinking Maps for 2 writings they have changed their feeling about English writing. 15 students thought Thinking Maps and the topic are connected with each other and form a whole. While they are writing using the maps, they feel writing becoming easier and clearer. Thus they are more confident while writing their own essays. Only two students have different opinions, one student still thinks writing is not easy and the other thinks that she is confused about the maps. Most of the students think Thinking Maps are clear and they can list more ideas on the maps. Instead of imitation writing, most of the students can have more thoughts by using Thinking Maps. The researcher believes that if all the students practice more, they will be skillful writers.

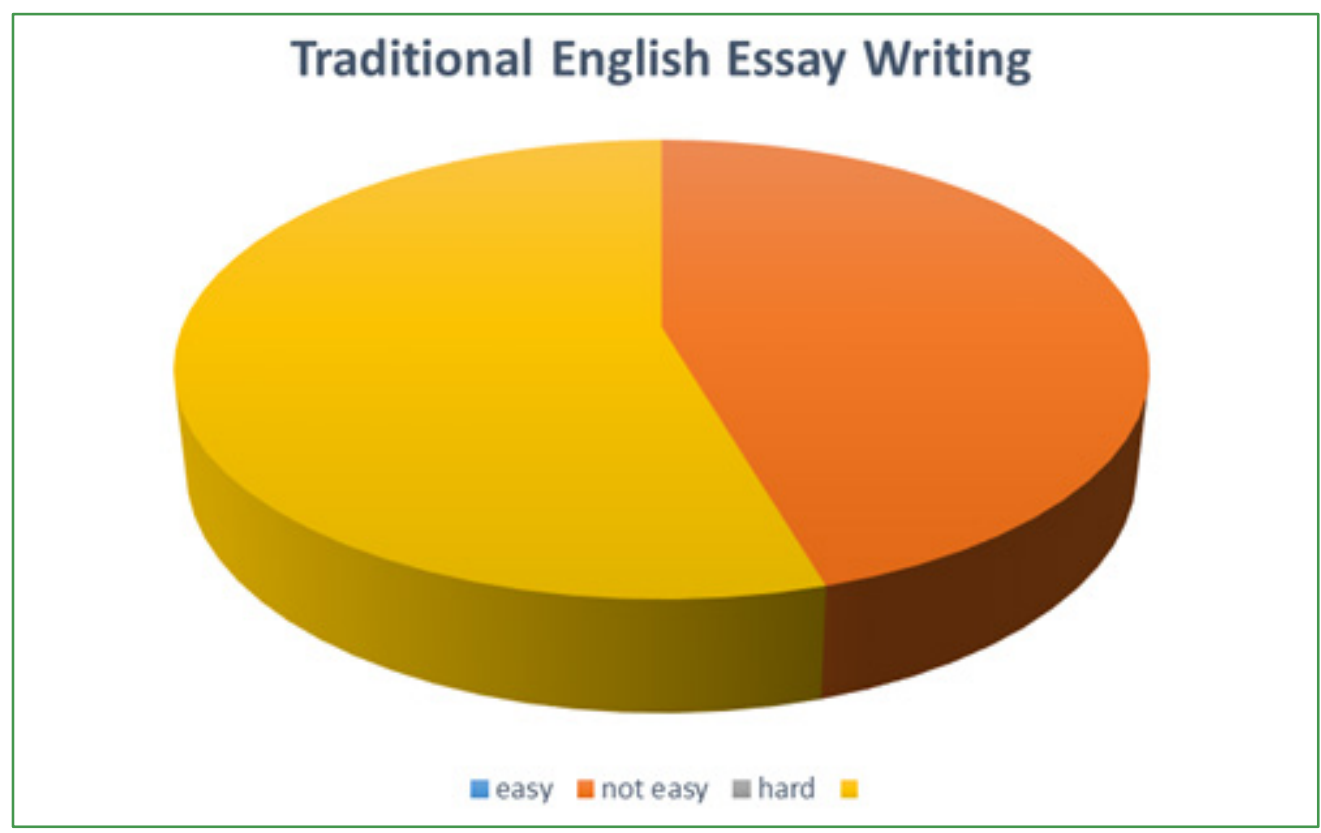

Figure 9. Interview all of the students about writing English essay before teaching Thinking Maps.

All of the students thought that English writing is not easy. They started writing after they had been learning English for one and half years, and they looked at me with a puzzled frown and it took a long time to finish writing. The researcher interviewed all of the students before they started their essay writing.

"I don't like writing especially writing in English. I have a hard time when I write," Student A replied.

"I have to think for a long time but I still don't have any ideas," Student B said. 


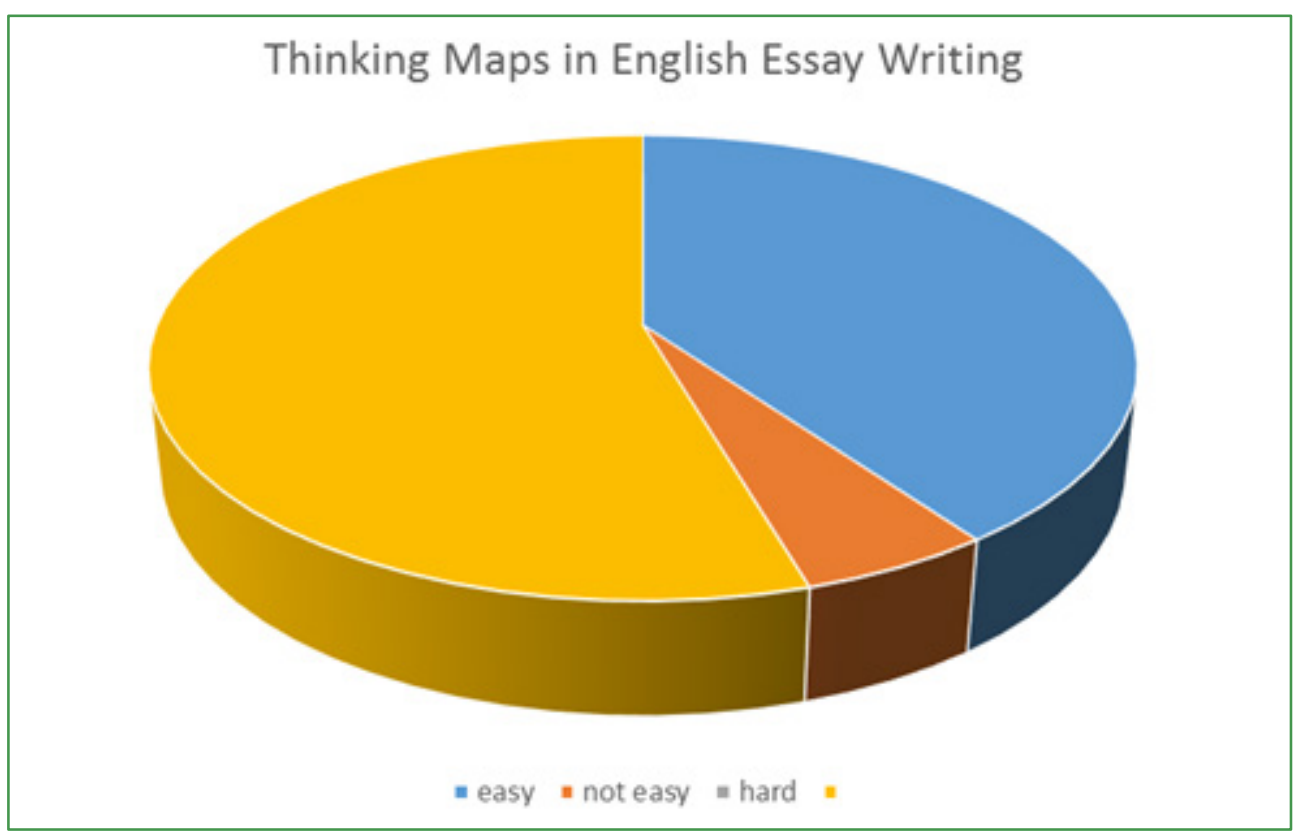

Figure 10. Interview all of the students about writing English essay after teaching Thinking Maps.

After introducing Thinking Maps to the students, they had more ideas and could organize their concepts together. The researcher interviewed all of the students after they finished their essay writing.

"While I am writing, my mind adds to my Thinking Maps all by itself, and I feel it is so useful!"

Student A said.

Student B said "Mmm... I am afraid of English writing but I think Thinking Maps help my writing."

Student C said "It is easy to write."

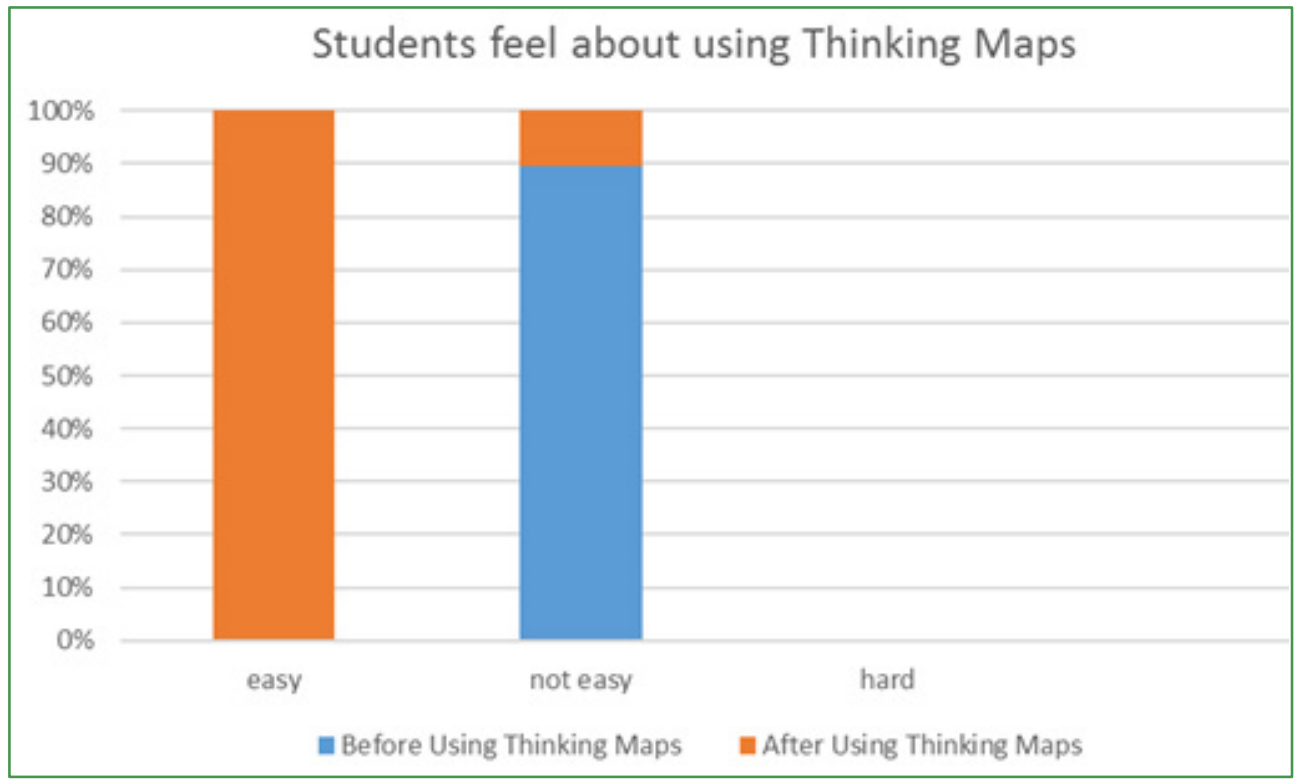

Figure 11. How the students feel about using Thinking Maps chart

There are two students who still have problems with using Thinking Maps. One still feels confused and the other one is still worried about writing. It takes time to learn a new way which can help them in English writing.

\section{Grading English Writing}

English writing is using the special symbols to map thoughts, which contains introduction, body and conclusion. In order to 
grade English writing fairly, I recommend more than two teachers do it. Centre of College Entrance Examination in Taiwan declared in 2009 that more 15 percentage of students had gotten a zero on their English writing. Taiwanese students who study English as a second language need to focus on planning, translating and reviewing in order to write better.

\section{Digital Grading}

Criterion Online Grading Website is a branch of Educational Testing Service or called ETS which invented the e-rater to grade online. After testing more than 1.3million GMAT tests, Criterion provides another way to grade English writing without downloading any software. Users may practice and grade English writing.

\section{- Second English Writing Project}

The researcher would like to see the effect of Thinking Maps on the freshmen, therefore the researcher tried to use Thinking Maps teaching a class of grade 6 students who have been learning English for more than 2 years in a public elementary school in Keelung. The students not only have the same ability in grammar and literacy, but also they are in the same age group. They have learned simple present tense and present continuous tense. They have never tried to write an essay before, this is the first time they will learn how to write an English essay. The researcher guides the students to start writing. Thinking Maps provide a good way to build writing structure and get ideas together. There is also a five- lesson curriculum in the second research, and the reading book is "Owl At Home". The literacy ability is limited because they have learned about 300 words. Though they haven’t learned a lot, it is still a great opportunity for them to try writing.

\section{- Conclusion of the Second English Writing Project}

There are 23 students in this class and they haven't got any chance to try before in the elementary school, the researcher questioned them after they learned how to use Thinking Maps.

\section{Feeling about using Thinking Maps to write}

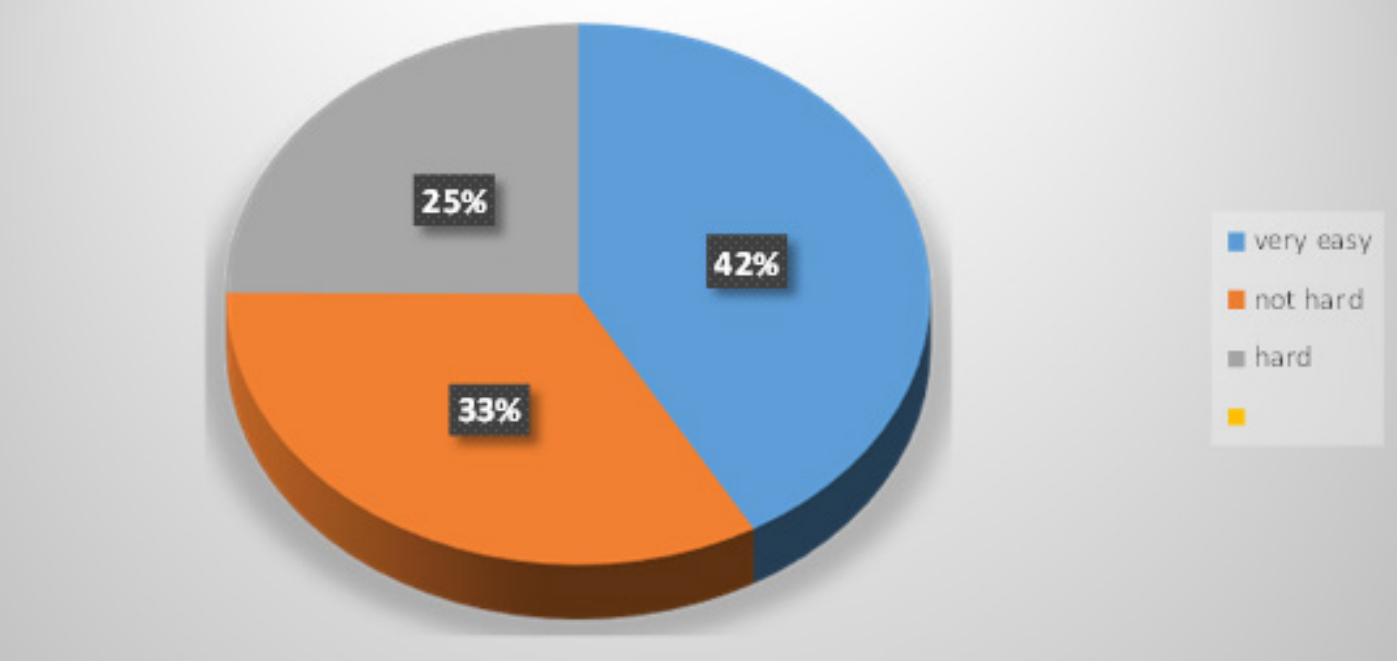

Figure 12. Students from the elementary school feel about using Thinking Maps to write

Most of the students think Thinking Maps are useful tools which help their writing structure but six students still think writing is really difficult for them. Therefore, the researcher looked for the reason why those students, whose English grades are under average and finding out that they have phonics and grammar problems learning English. The researcher has only taught this class for one year, therefore questioning previous English teacher is needed. Since the previous English teacher transferred to the other school for a few years, it seems hard to get the reason. 


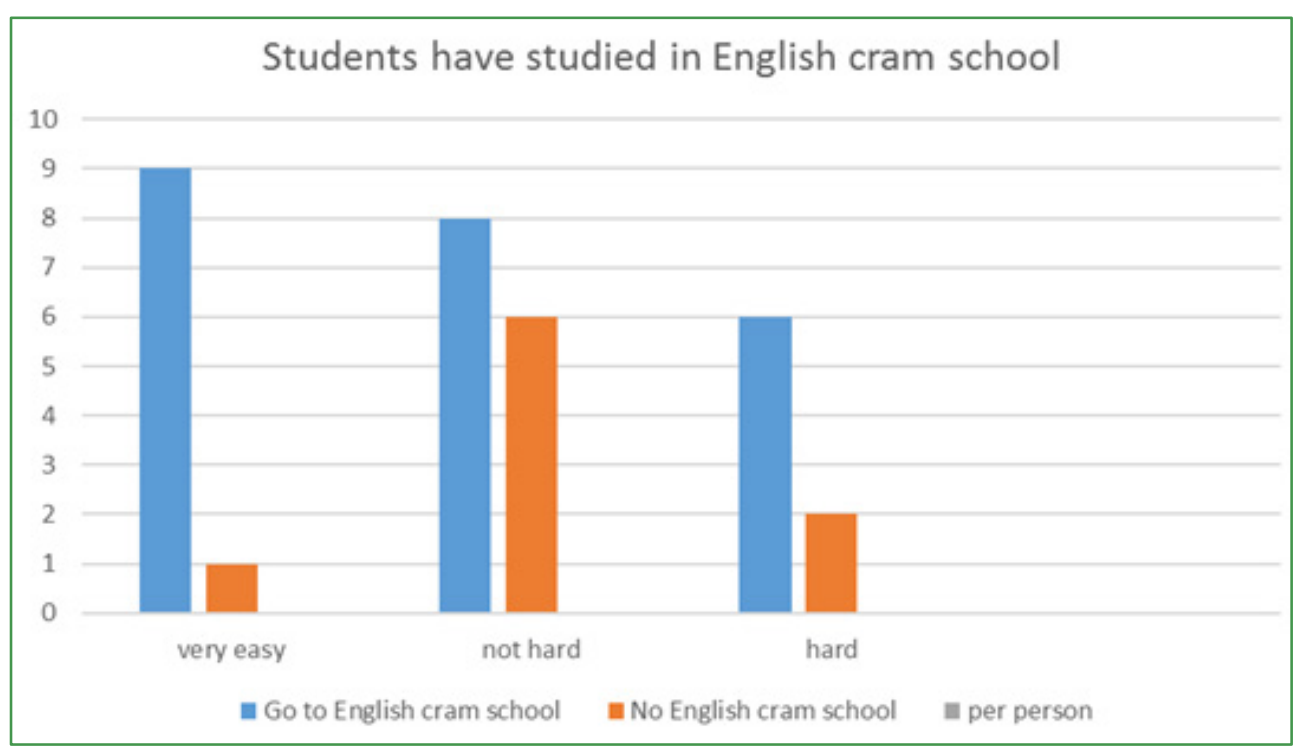

Figure 13. Students from a cram school feel about using Thinking Maps to write

Most of the students study in English cram schools in Taiwan. From the chart it is obvious that Thinking Maps make the students feel writing is not hard.

\section{Findings}

After the interviews, we found out that most of the students go to English cram schools when they start English class at school, yet their writing ability isn't built up. It is hard to hold the ideas in our brain and Thinking Maps help the teachers save time. Instead of wasting time and having poor ideas, Thinking Maps will help most of the students in developing good structure, providing more and more ideas for them to use in their own essay writing no matter if they have experience in writing or not. Thinking Maps support the useful methods, clear structures for the students and help students focus on English writing structure. They provide students with tools they can use to examine and visually represent relationships in English writing and help students write well-organized essays. We should observe the students and also pay special attention to their progress after they use Thinking Maps in English writing.

\section{Index}

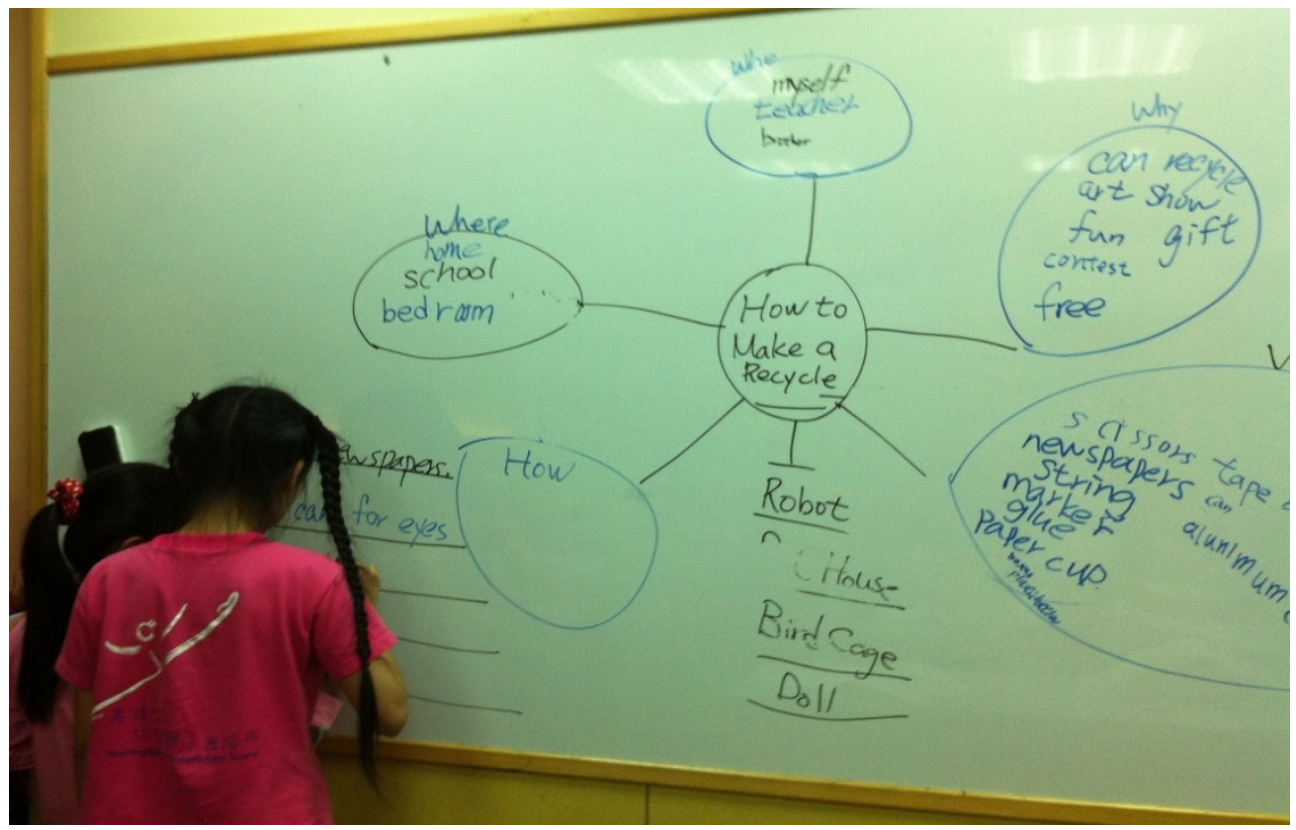

Figure 1. Cram school students work out with Tree Maps. 


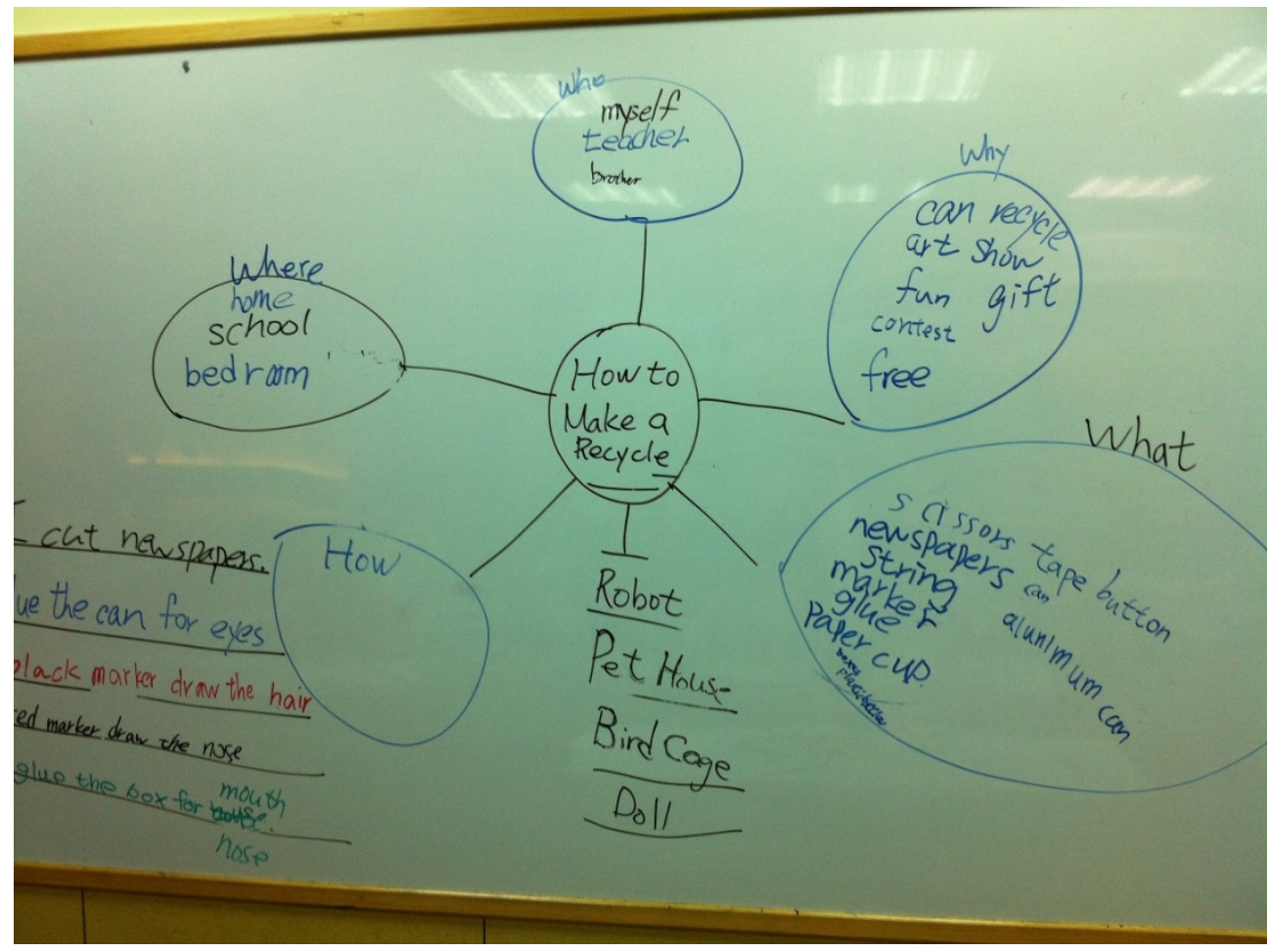

Figure 2. Thinking Maps on the board of cram school students

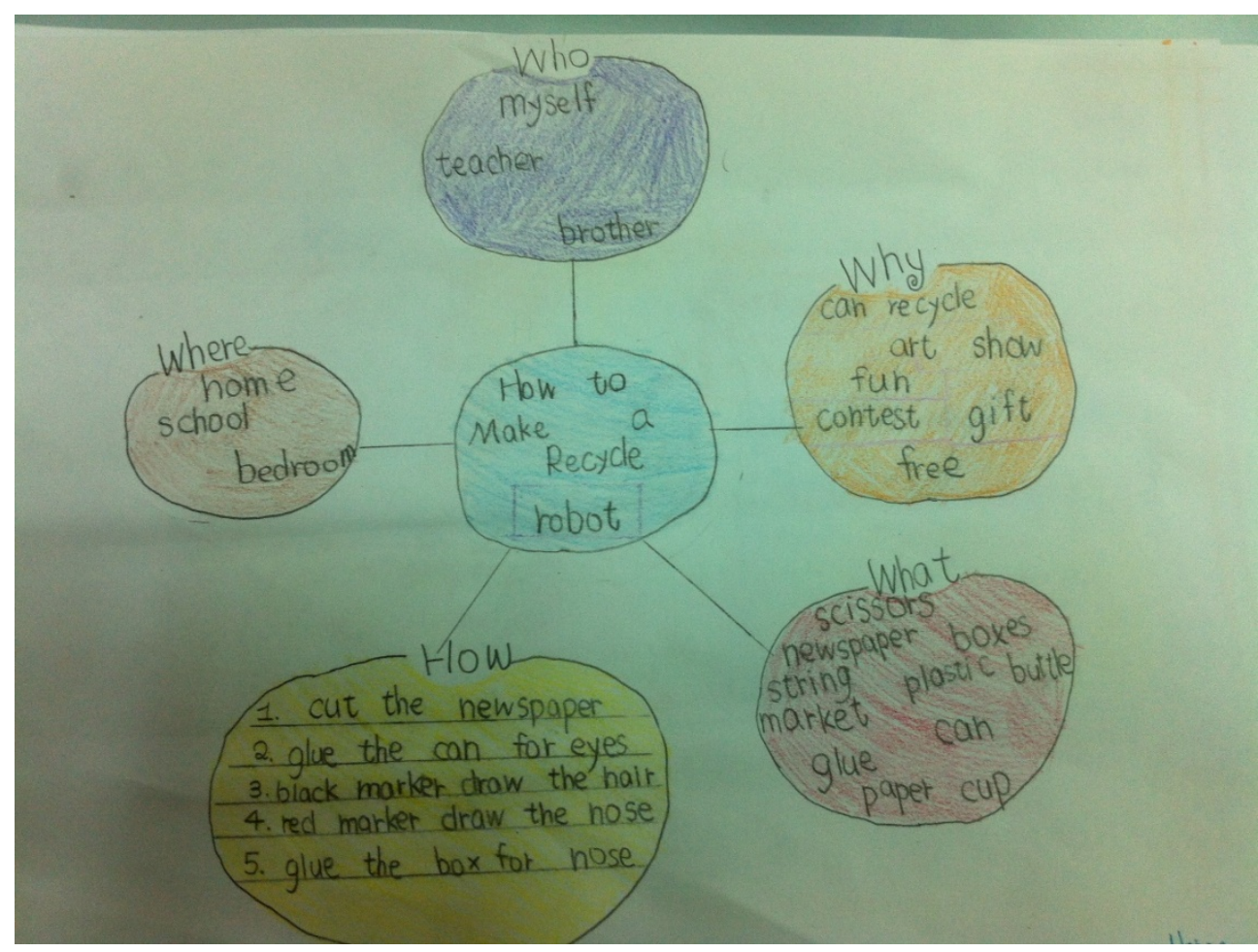

Figure 3. Thinking Maps from one of the students in cram school students 


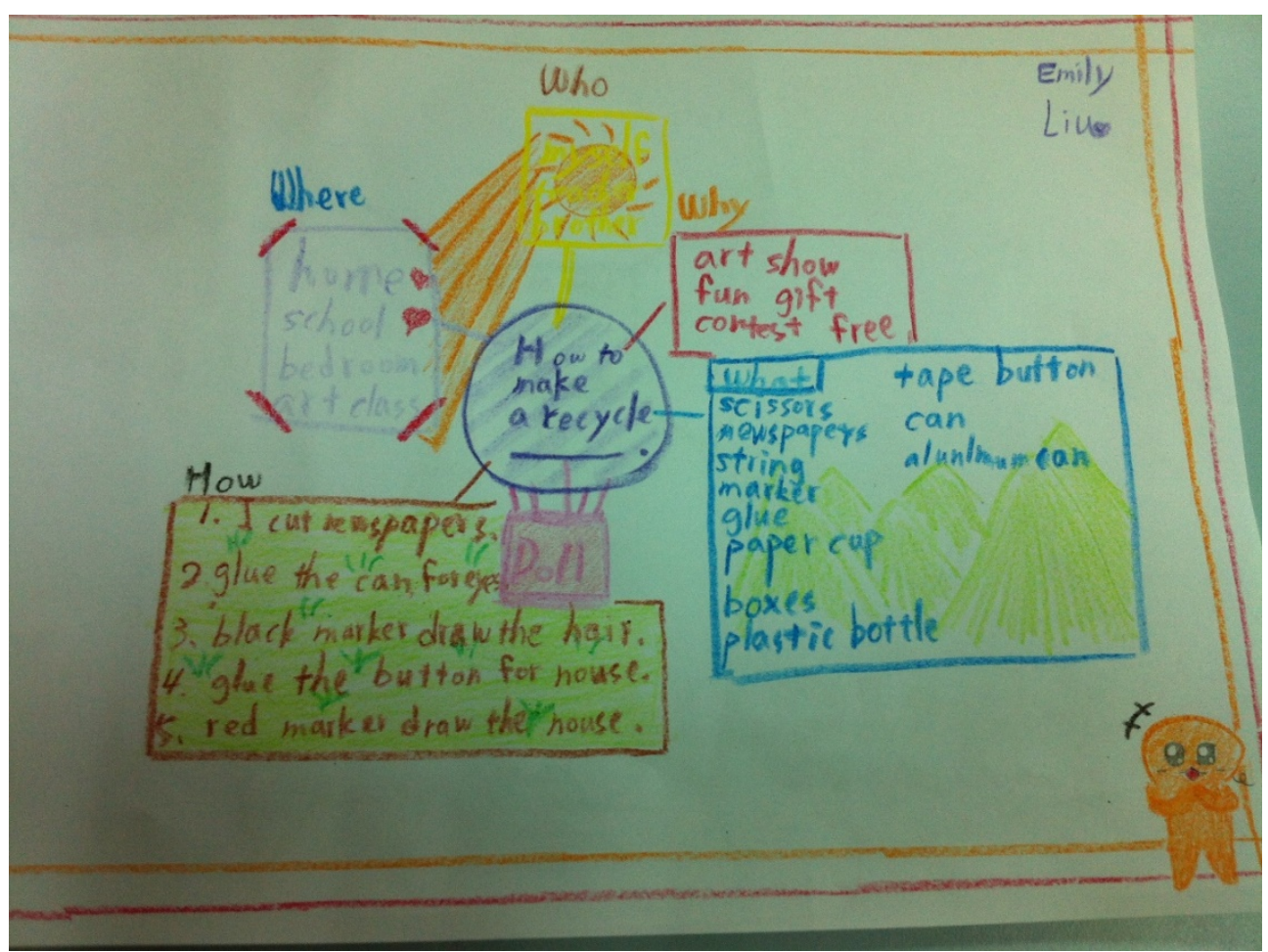

Figure 4. Thinking Maps from one of the students in cram school students

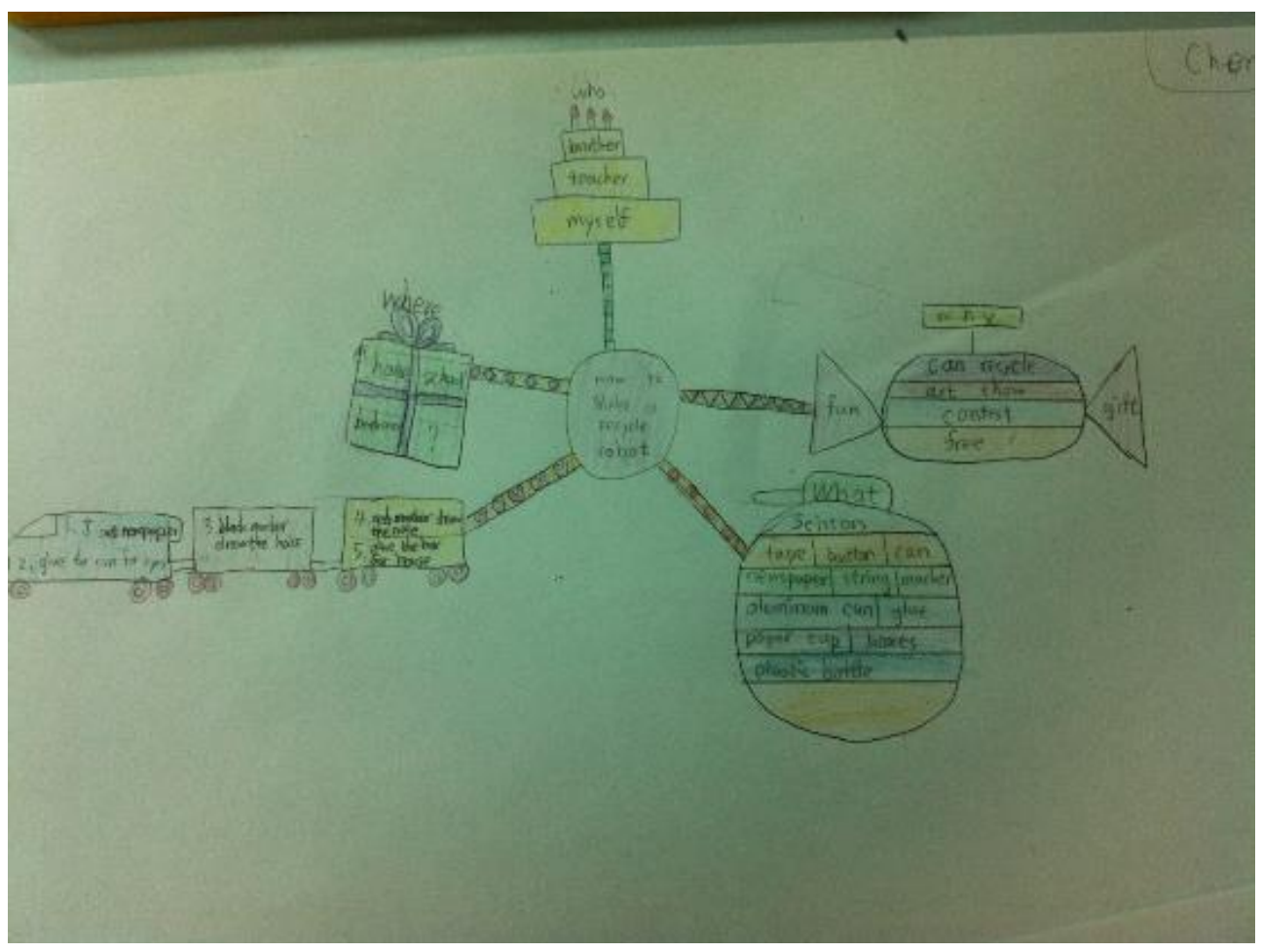

Figure 5. Thinking Maps from one of the students in cram school students 


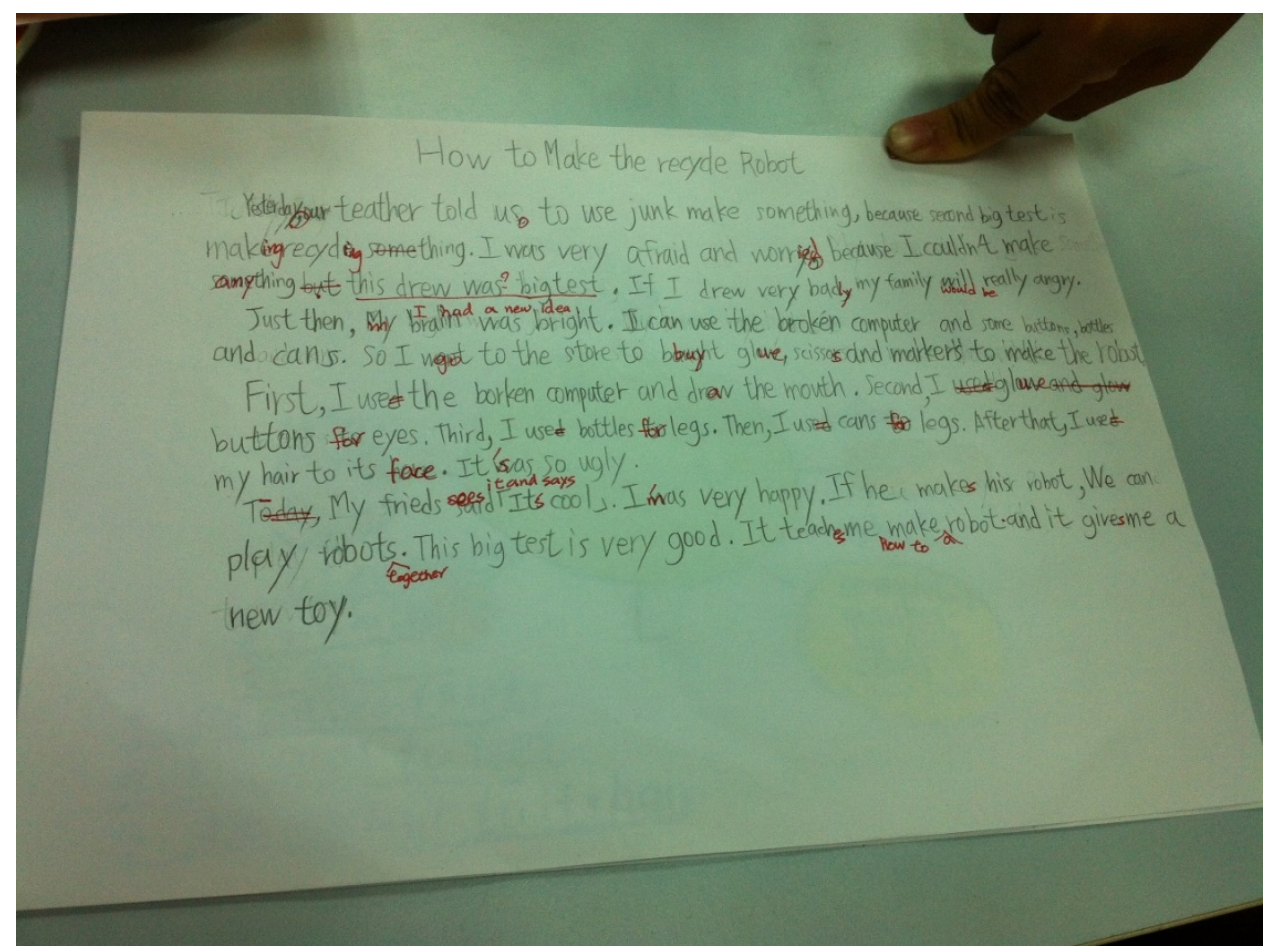

Figure 6. Luke's Essay from cram school

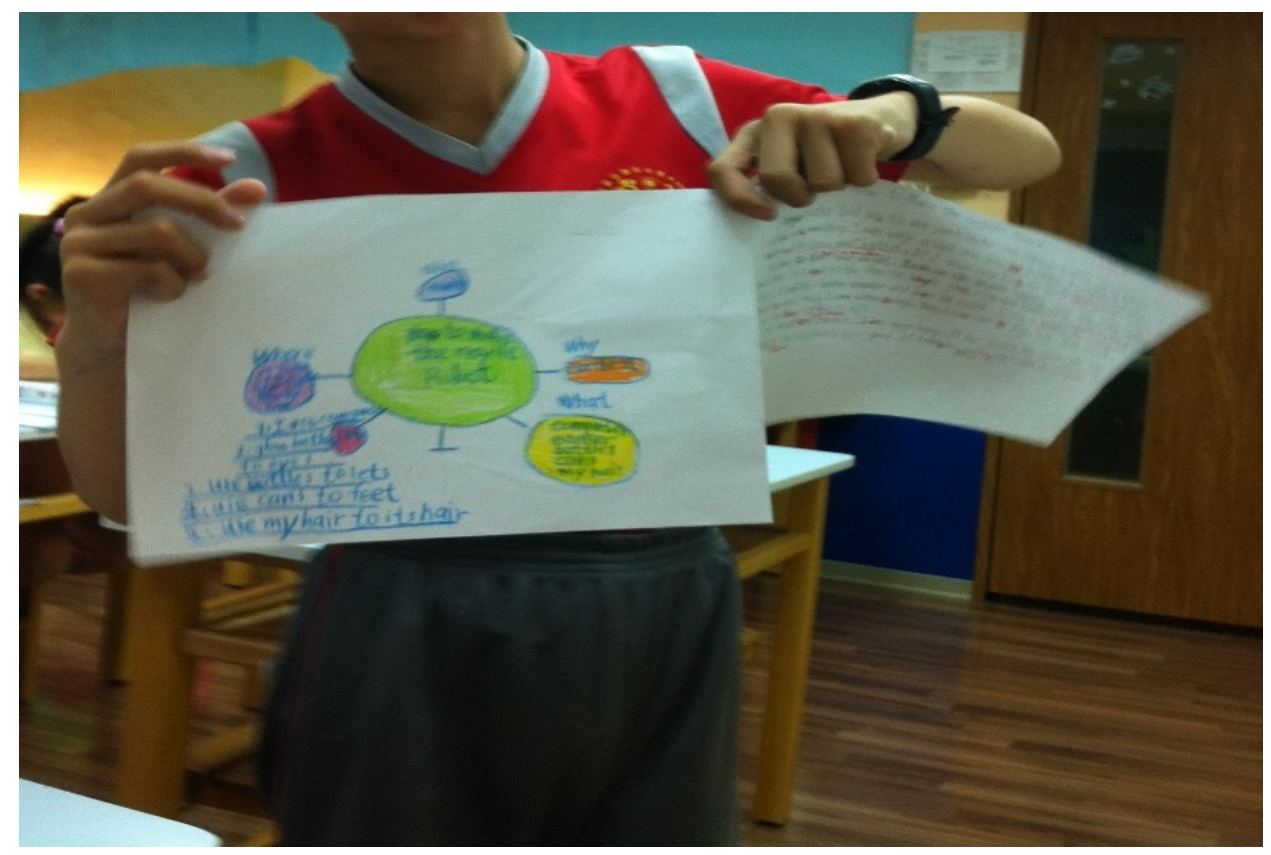

Figure 7. Luke's Essay and his Thinking Maps 


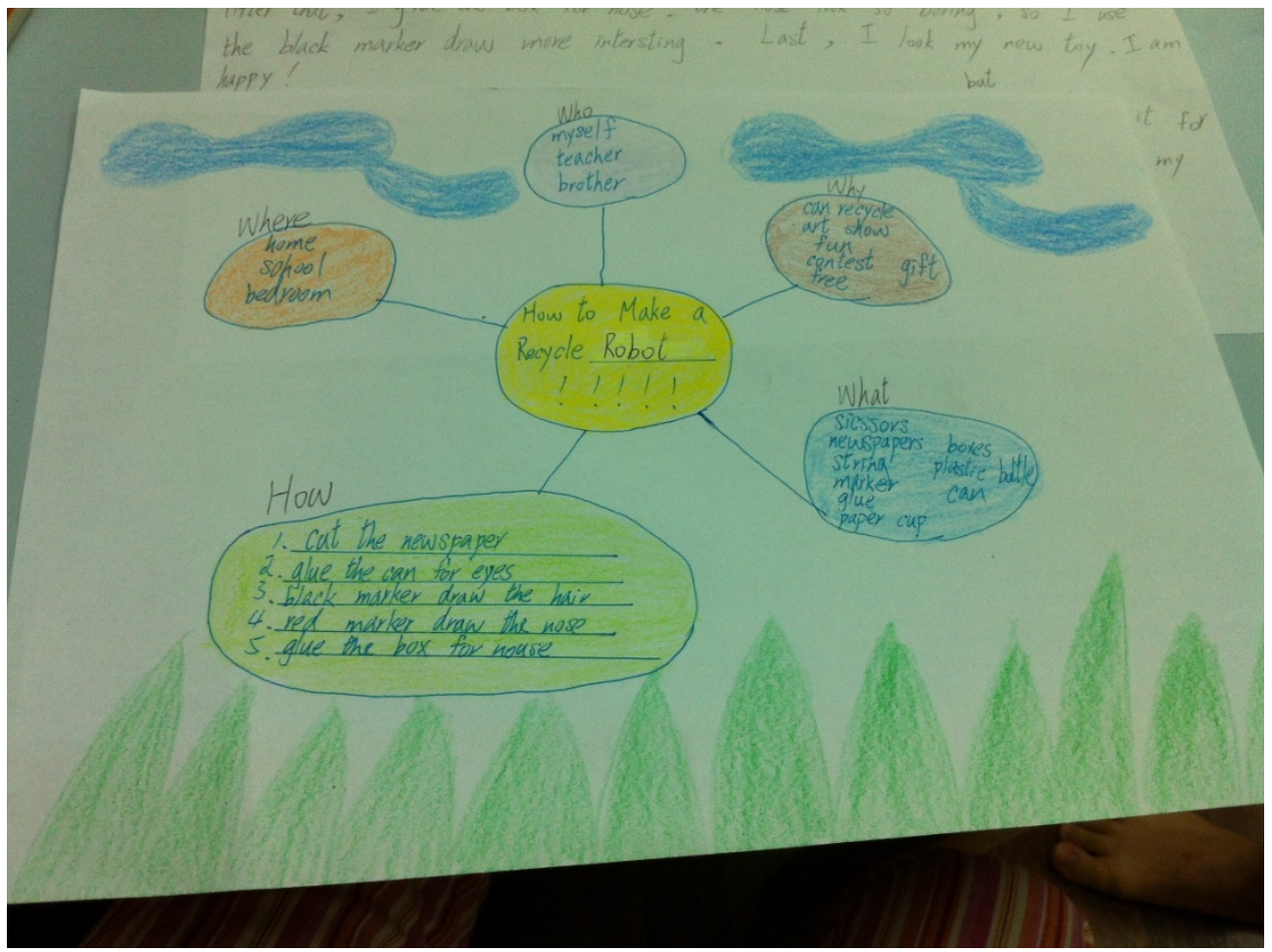

Figure 8. Bubble Maps and Tree Maps in cram school

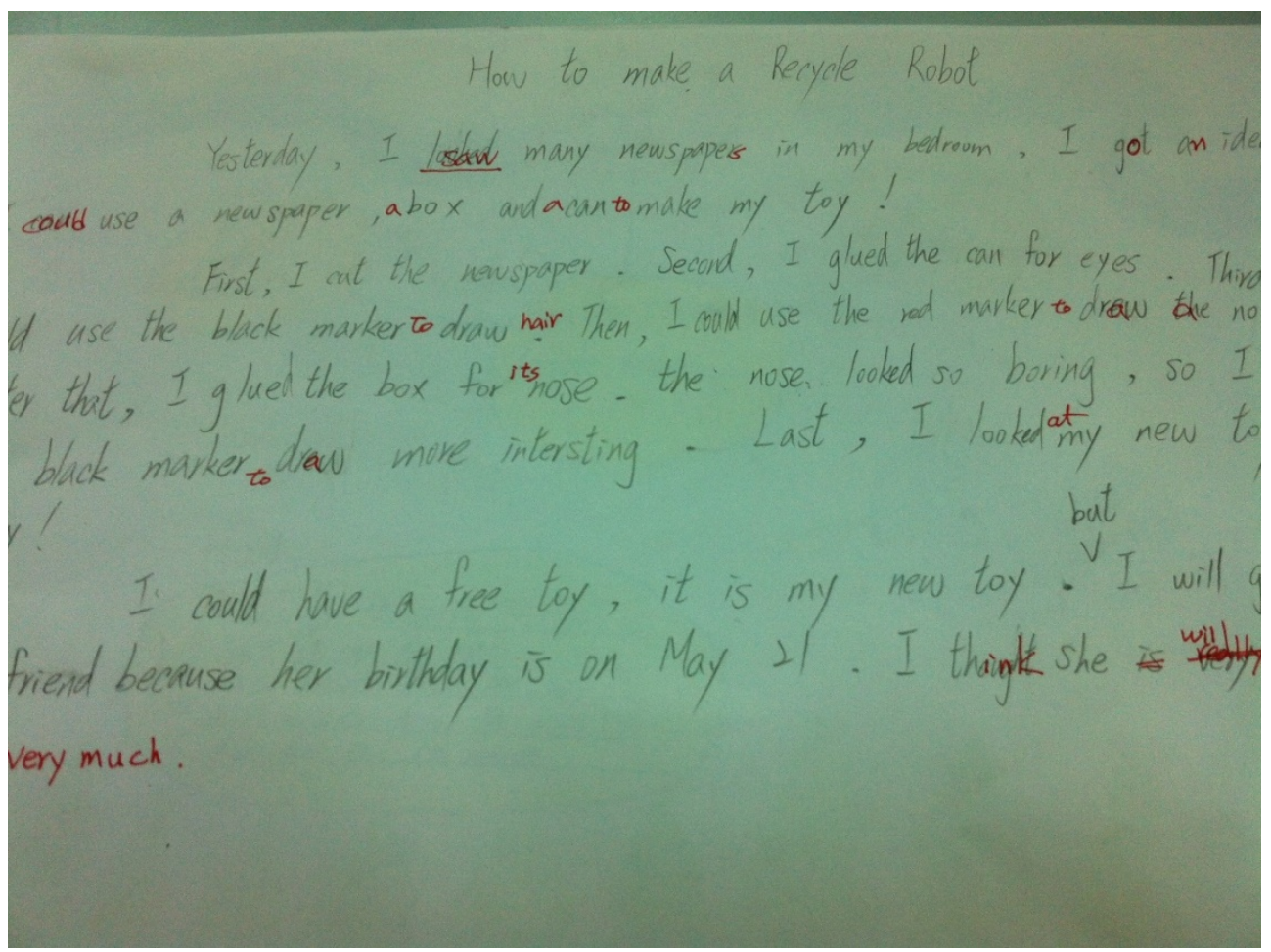

Figure 9. Writing after using Thinking Maps in cram school students 


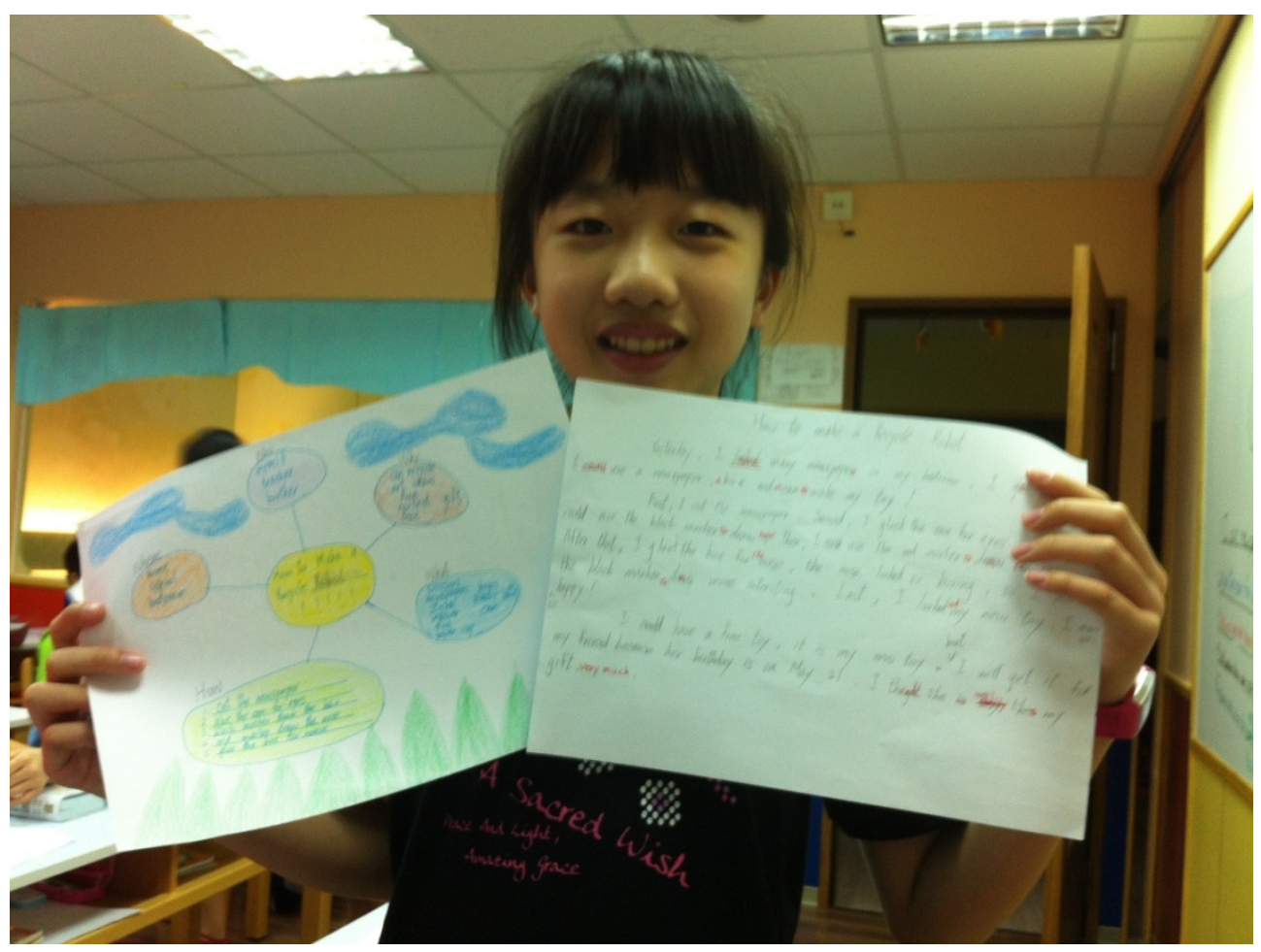

Figure 10. Vivian's Essay and her Thinking Maps from cram school

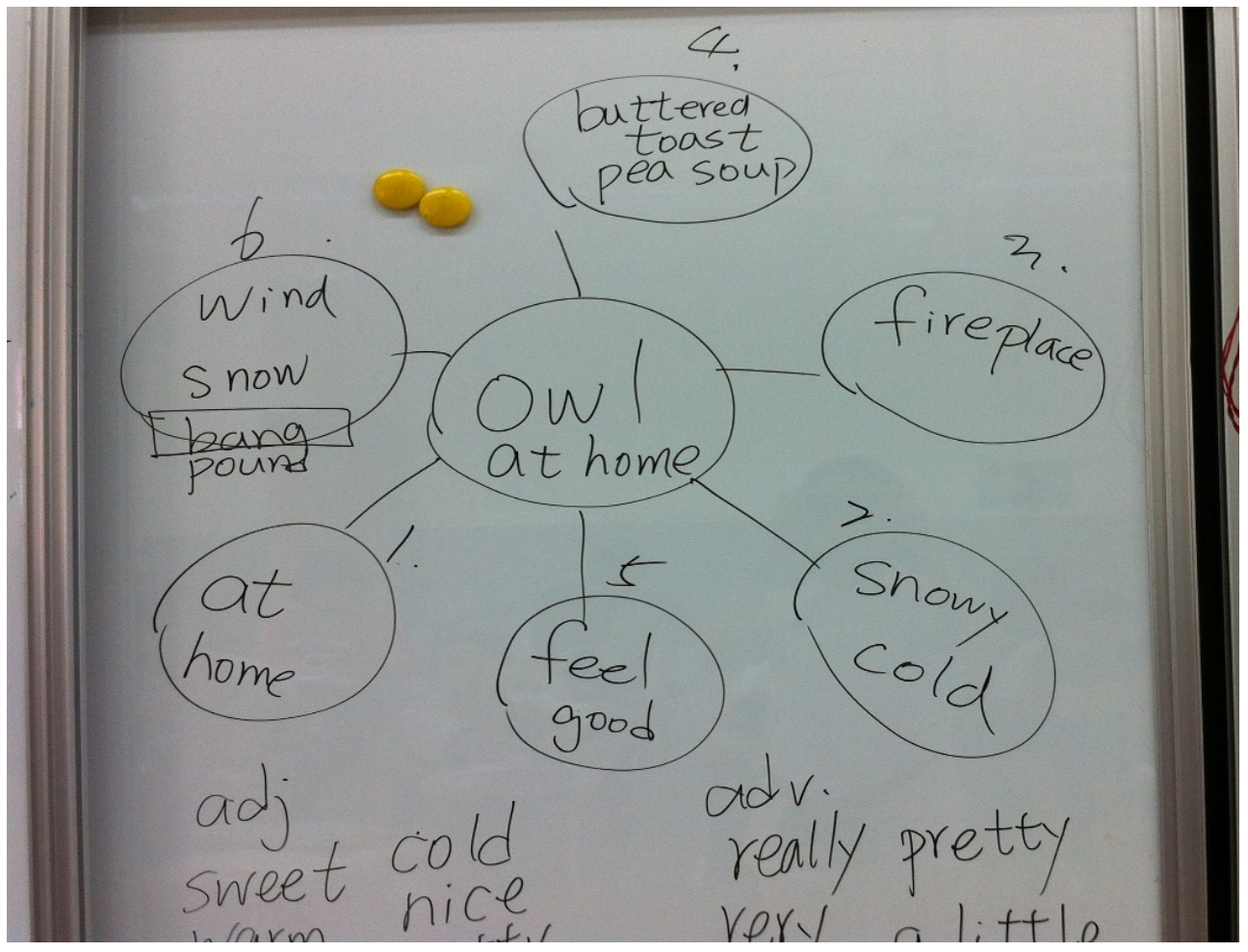

Figure 11. Bubble Maps for the main idea from grade 6 in the elementary school 


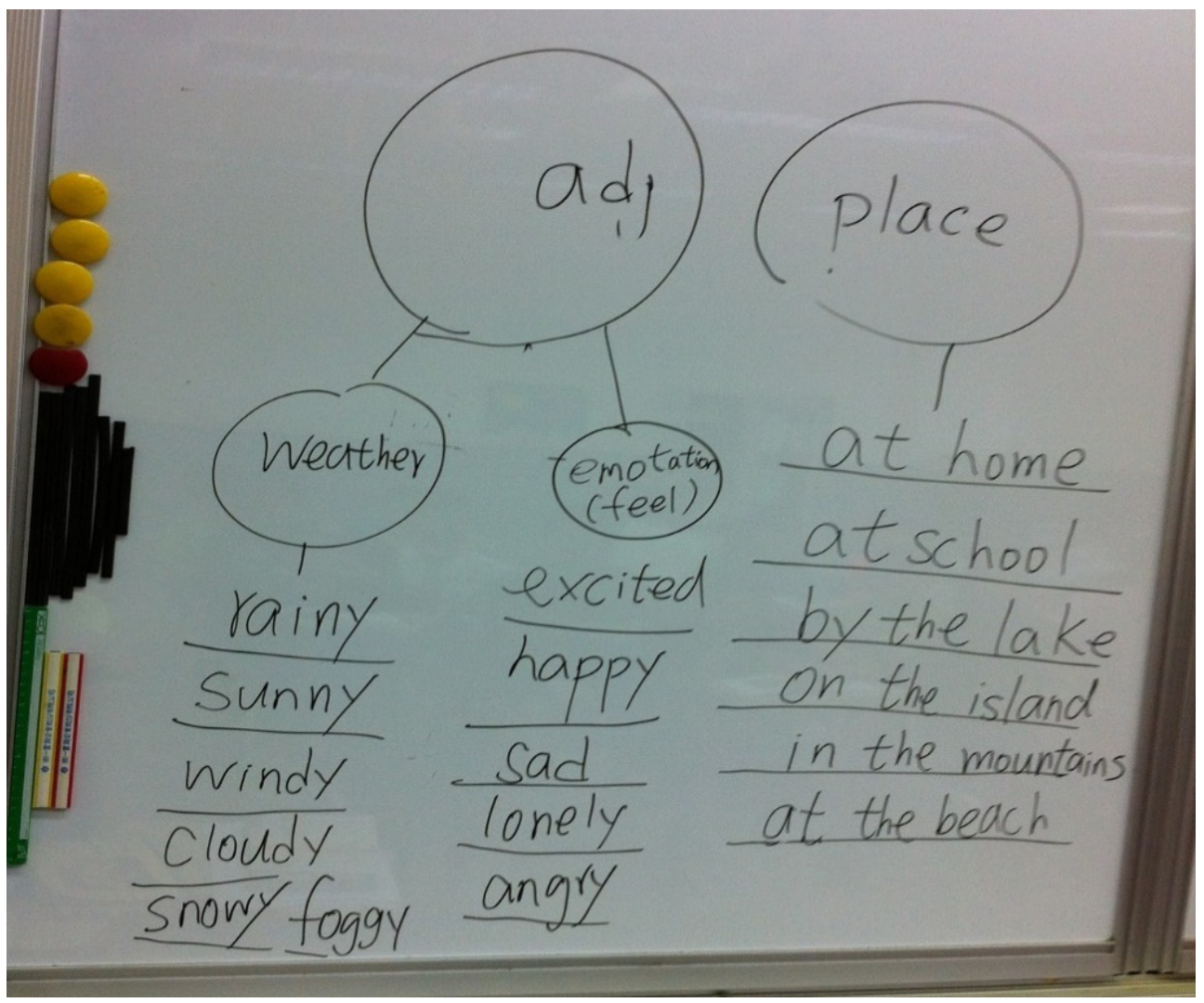

Figure 12. Bubble Maps and Tree Maps for Adjectives and Places from grade 6 in the elementary school

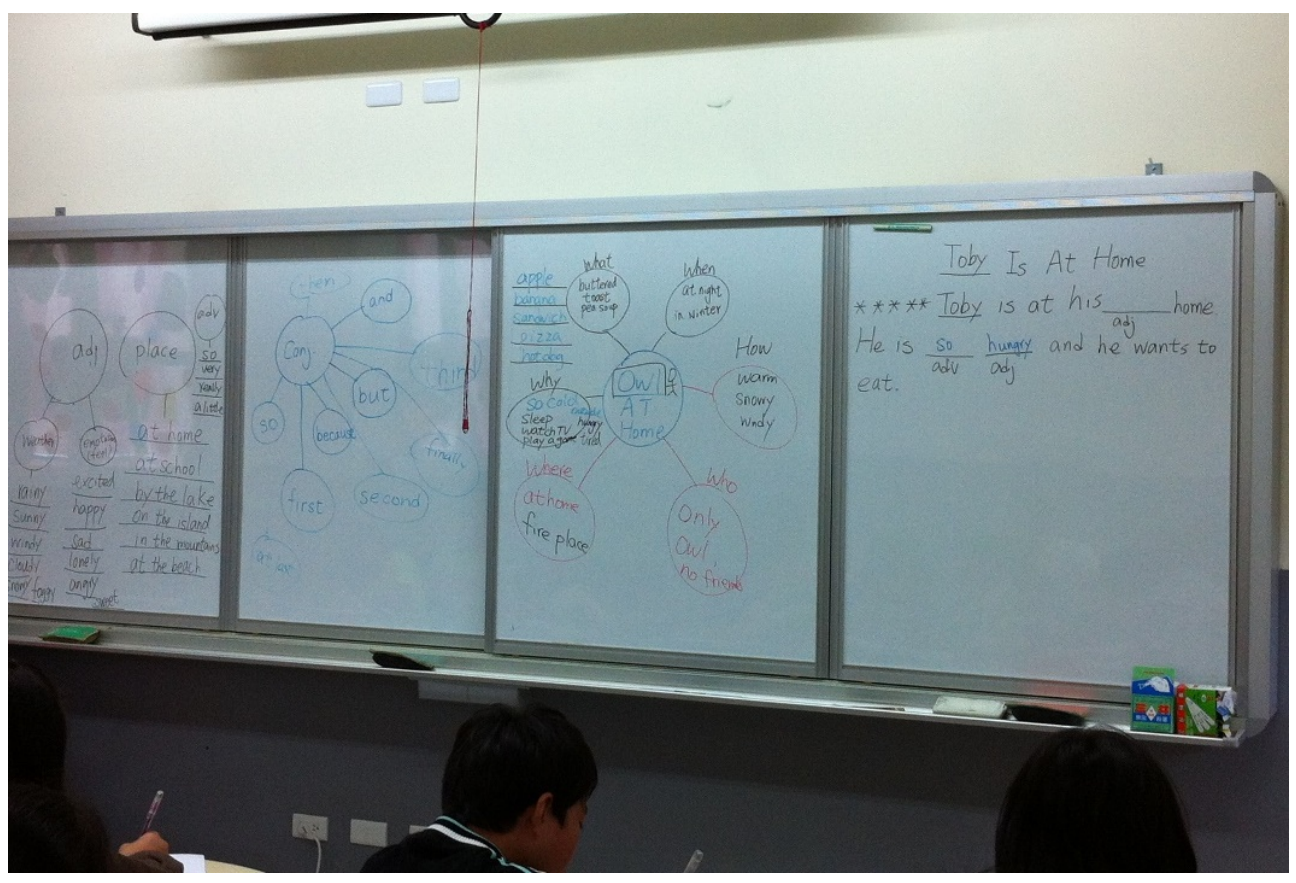

Figure 13. Thinking Maps on the board from grade 6 in the elementary school 


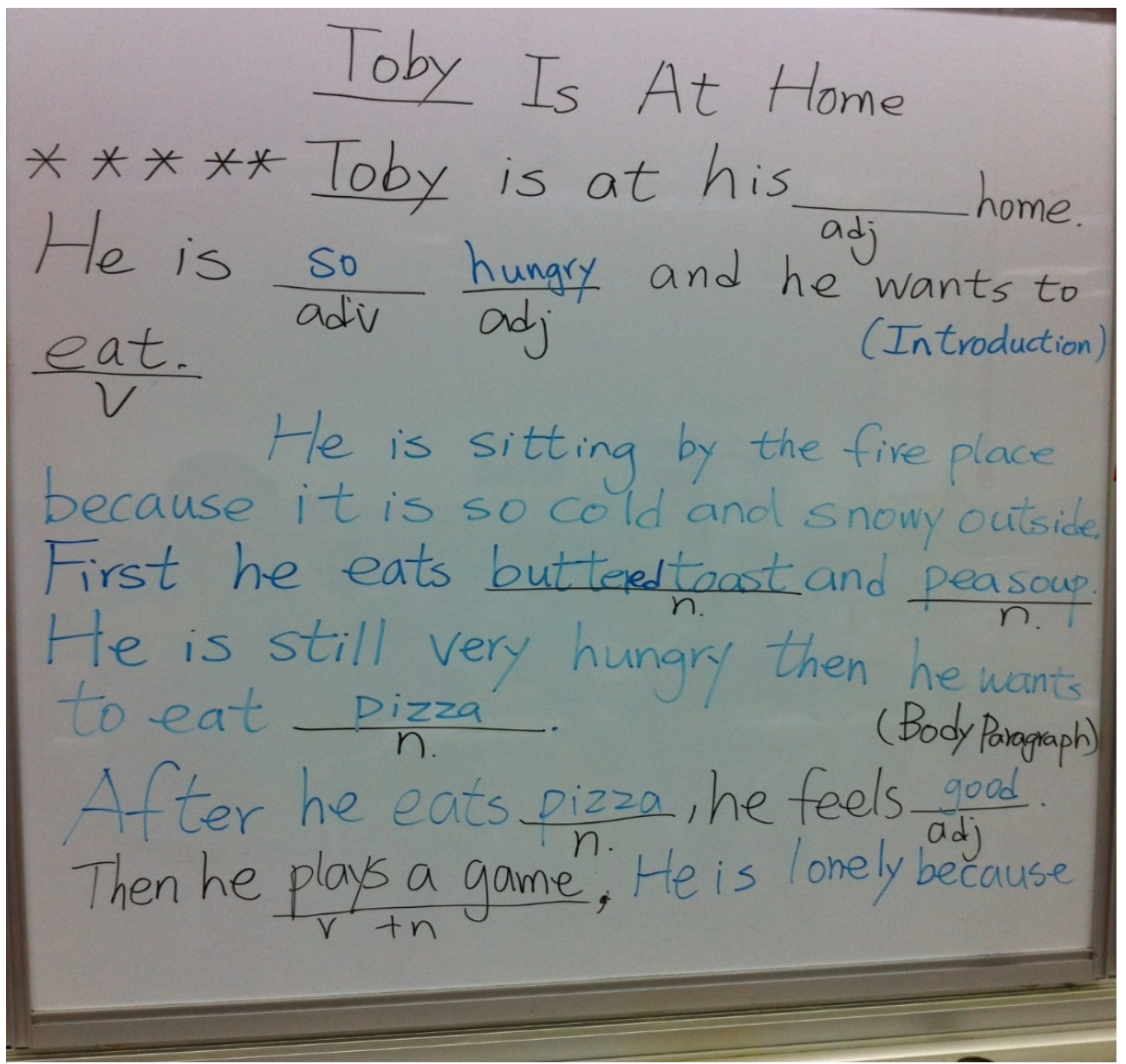

Figure 14. Imitation Writing from grade 6 in the elementary school

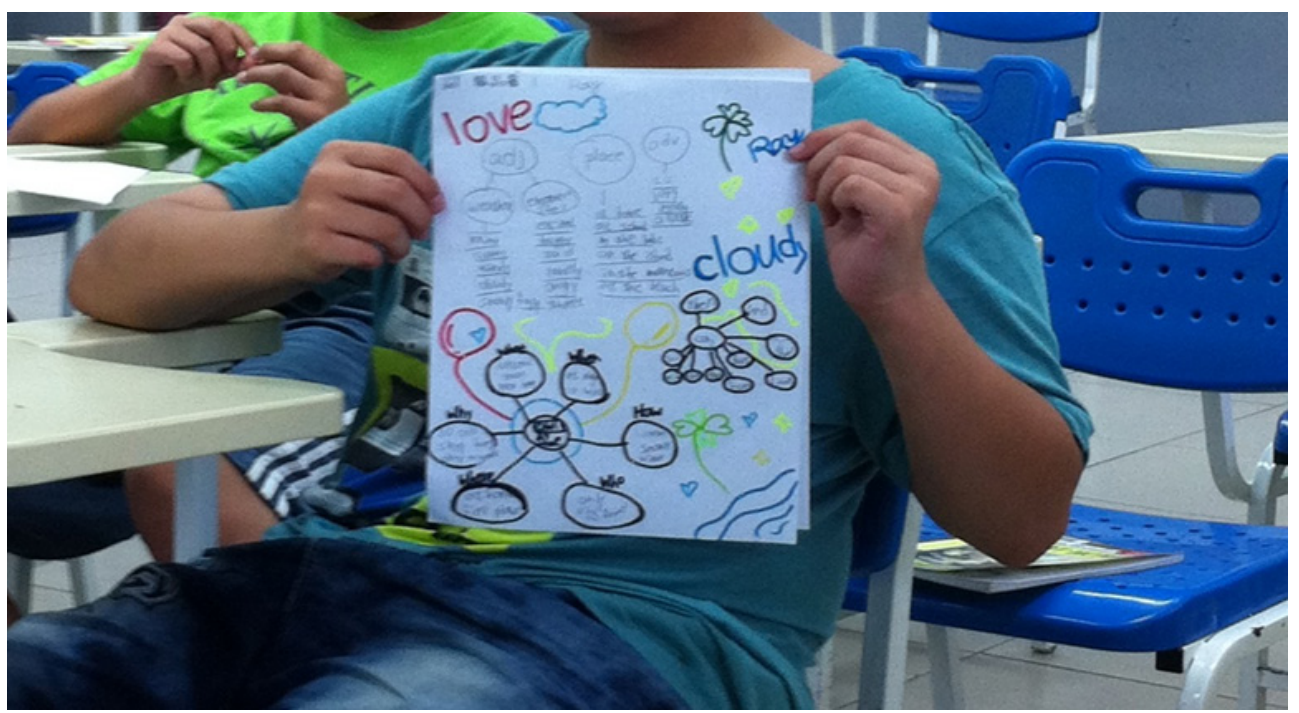

Figure 15. One boy finished his Bubble Maps and Tree Maps in the elementary school 


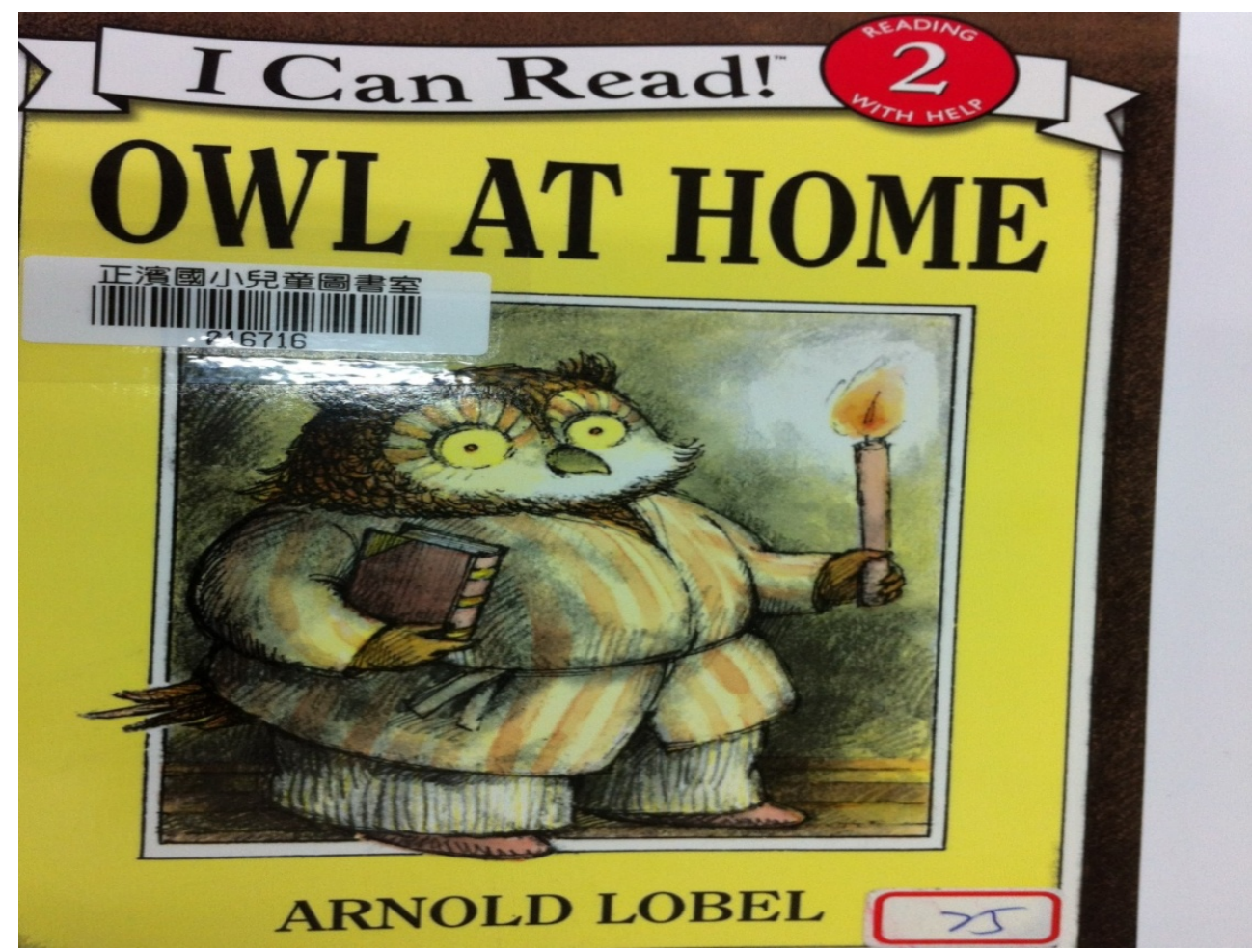

Figure 16. OWL AT HOME

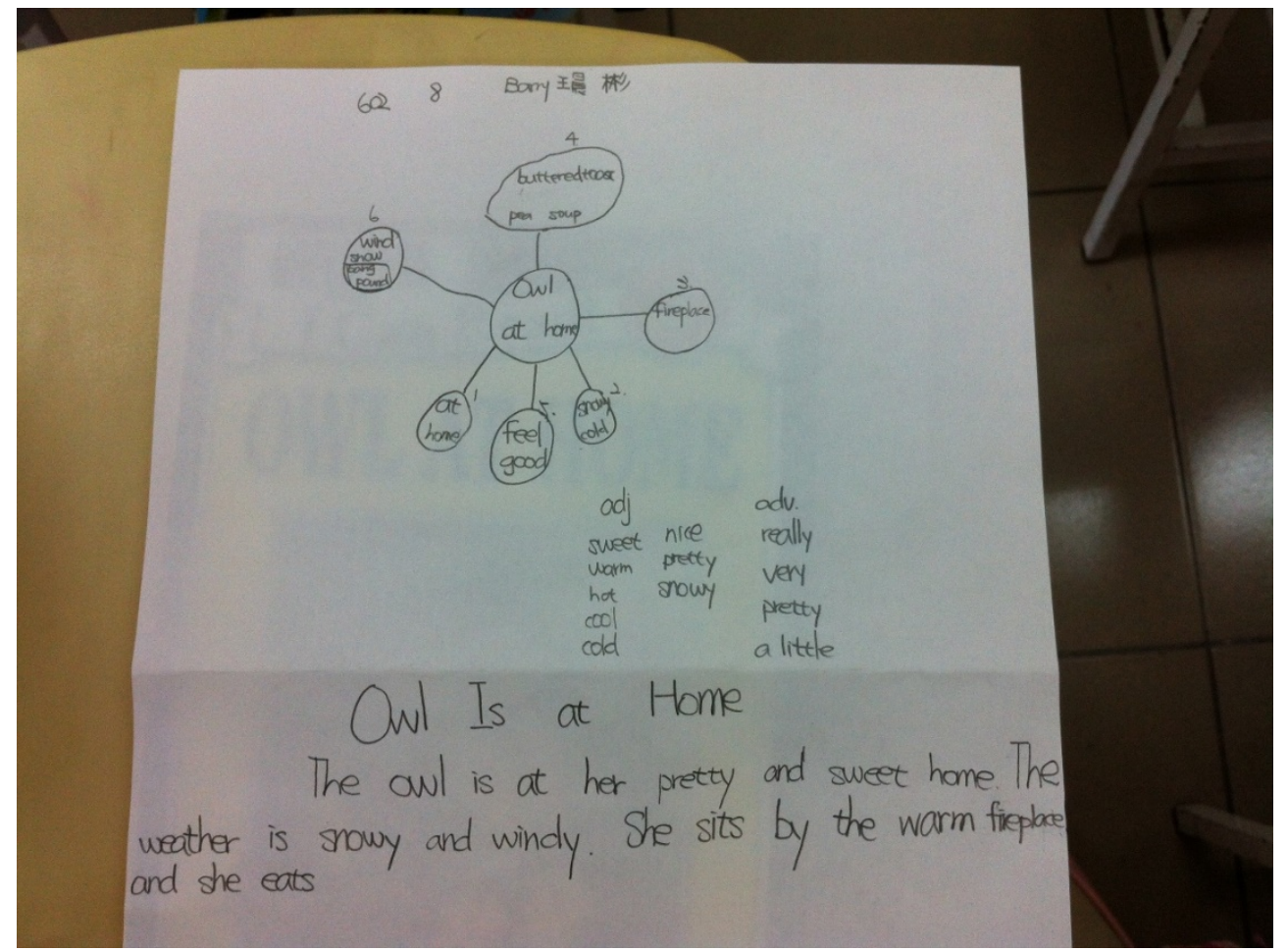

Figure 17. Barry's Thinking Maps and outline the ideas from the story 


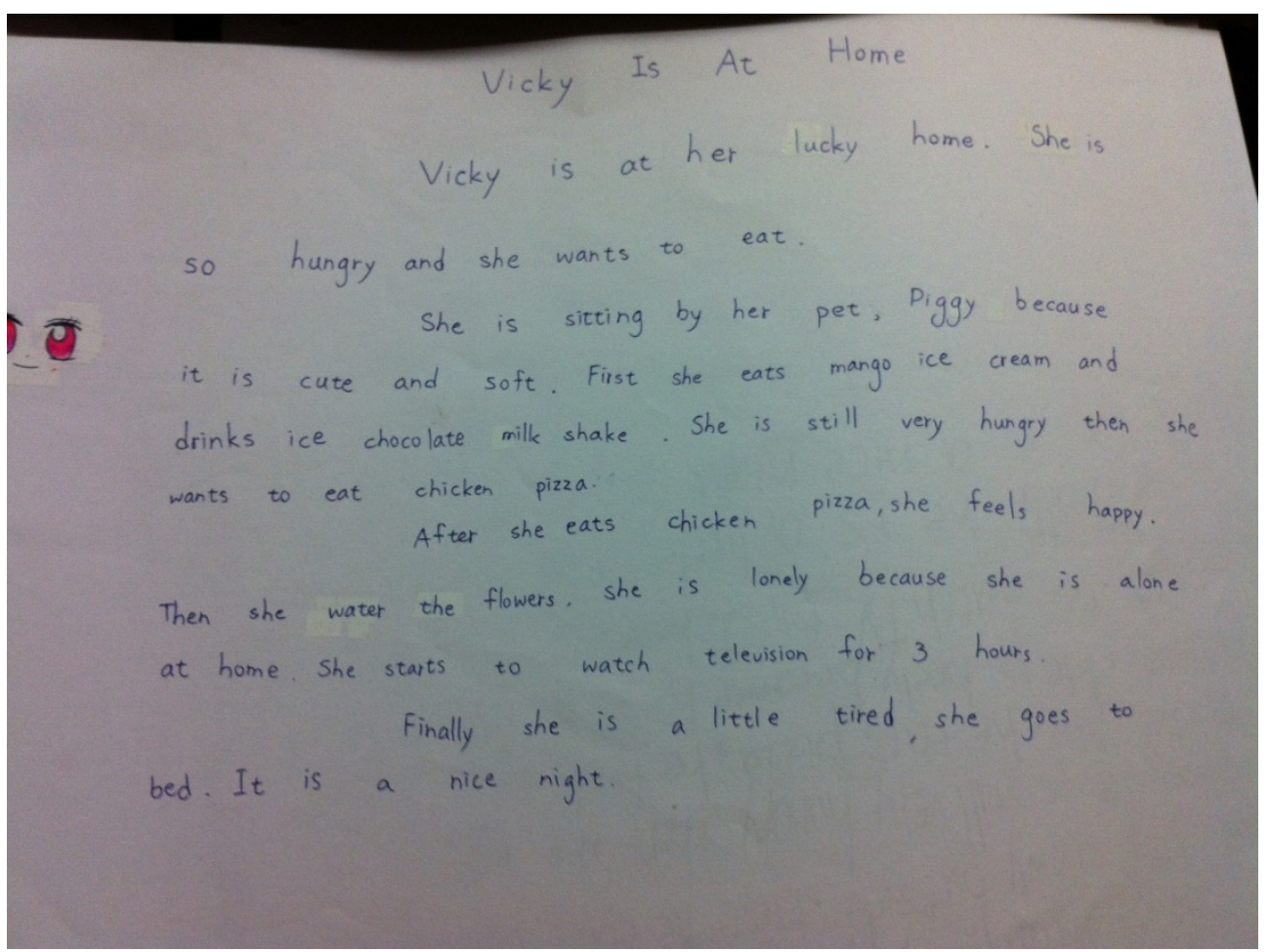

Figure 18. Ivy's imitation writing

\section{REFERENCES}

[1] David N. Hyerle : Visual Tools for Transforming Information Into Knowledge, Corwin Press,2009.

[2] David N. Hyerle: Larry Alper : Student Successes With Thinking Maps, second edition, School-Based Research, Results, and Models for Achievement Using Visual Tools, Corwin Press, 2013.

[3] Moyles, Janet R.: The excellence of play, Buckingham : Open University Press, 1994

[4] Nancy Kathleen File:Children's play and teacher-child interactions in integrated early childhood programs, Michigan : A Bell \& Howell,1994.

[5] Noffke, S. E. \& Stevenson,R. B.. "Eds.) Educational action research: Becoming practically critically. New York: Columbia University Teacher College.", 1995.

[6] Robert Klanten, Hendrik Hellige: Play loud!, Berlin : Die Gestalten Verlag,2006

[7] Scarlett, W. George: Children's play/ W. George Scarlett ... [et al.], Thousand Oaks : Sage Publications,2005.

[8] Schaefer, Charles E.: Game Play, New York : John Wiley and Sons, 1986

[9] Schon: Educating the reflective practitioner, London: Jossey-Bass, 1987.

[10] Seach, Diana: Interactive play for children with autism, Abingdon, Oxon : Routledge, c2007

[11] Step Ahead English Series, 2005, Hess educational Enterprise Co., Ltd

[12] http://thinkingmaps.com/ software from Thinking Map 2.06

[13] Jane C. Buckner, ED.S, Path to Proficiency for English Language Learners Includes. Training Manual in 3-ring binder

[14] Gail E. Tompkins,2008, Teaching Writing Balancing Process and Product, Pearson/Merrill/Prentice Hall

[15] Flower,L (19890. Taking thought: The role of conscious processing in the making of meaning. In E. P. Maimon, B. F. Nodine,\&F. W. O'Connor (Eds.) Thinking reasoning and writing (pp.185-212). New York: Longman.

[16] http://thinkingmaps.com/pdfdocs/PathtoProficiencyPreviewP acket.pdf 